\title{
Developments in Intellectual Property LaW: OCTOBER 1, 2019 - SEPTEMBER 30, 2020
}

\author{
R. TREVOR CARTER* \\ LESLIE B. HAYDEN** \\ REID E. DODGE ${ }^{* * *}$
}

This Article addresses recent developments in intellectual property law. In particular, this Article provides an overview and discussion of nine important intellectual property law cases argued and/or decided between October 1, 2019, and September 30, 2020. Four of these decisions come from the United States Supreme Court, three come from the United States Court of Appeals for the Federal Circuit (the "Federal Circuit") or the United States Court of Appeals for the Ninth Circuit (the "Ninth Circuit"), one comes from the Indiana Court of Appeals, and the remaining decision comes from the Patent Trial and Appeal Board (the "Board"). The cases are:

- Thryv, Inc. v. Click-To-Call Technologies, $L P^{1}$;

- Romag Fasteners, Inc. v. Fossil, Inc.

- Georgia v. Public.Resource.Org, Inc. ${ }^{3}$;

- U.S. Patent \& Trademark Office v. Booking.com B.V.;

- In re Google $L L C^{5}$;

- American Axle \& Manufacturing, Inc. v. Neapco Holdings LLC

- $\quad$ Skidmore v. Led Zeppelin ${ }^{7}$;

- Warsaw Orthopedic, Inc. v. Sasso ${ }^{8}$; and

- Apple, Inc. v. Fintiv, Inc. ${ }^{9}$

\section{APPEALABILITY OF INTER PARTES REVIEW TIME-BAR DECISIONS: THRYV, INC. V. CLICK-TO-CALL TECHNOLOGIES, LP}

On April 20, 2020, a divided U.S. Supreme Court held that inter partes review ("IPR") time-bar determinations under 35 U.S.C. § 315(b) constitute nonappealable institution decisions pursuant to 35 U.S.C. $\S 314(\mathrm{~d}) .{ }^{10}$ According to

* R. Trevor Carter is a partner with the law firm Faegre Drinker Biddle \& Reath LLP in Indianapolis, Indiana.

** Leslie B. Hayden is Senior Legal Counsel for MACOM Technology Solutions Inc.

*** Reid E. Dodge is an associate in Faegre Drinker's Indianapolis, Indiana office.

1. 140 S. Ct. 1367 (2020).

2. 140 S. Ct. 1492 (2020).

3. 140 S. Ct. 1498 (2020).

4. 140 S. Ct. 2298 (2020).

5. 949 F.3d 1338 (Fed. Cir. 2020).

6. 966 F.3d 1347 (Fed. Cir. 2020).

7. 952 F.3d 1051 (9th Cir. 2020).

8. 162 N.E.3d 1 (Ind. Ct. App. 2020).

9. No. IPR2020-00019, 2020 WL 2126495 (P.T.A.B. Mar. 20, 2020).

10. Thryv, Inc. v. Click-To-Call Techs., LP, 140 S. Ct. 1367, 1373 (2020). 
the Court, such determinations are "closely tied" to the decision to institute IPR. ${ }^{11}$

\section{A. America Invents Act Background}

The America Invents Act ("AIA") created IPR, which allows third parties to challenge issued patents by petitioning for the institution of an IPR. ${ }^{12}$ Section 314(a) provides that an IPR may not be instituted unless "there is a reasonable likelihood that the petitioner would prevail with respect to at least 1 of the claims challenged in the petition." ${ }^{13}$ Additionally, an IPR may not be instituted if it is filed more than one year after the petitioner has been sued for patent infringement. ${ }^{14}$ By statute, the Board's "determination" whether to institute an IPR is "final and nonappealable." 15 Only once the Board issues a final written decision on the validity of the challenged claims, "[a] party dissatisfied with the final written decision ... may appeal the decision' to the Court of Appeals for the Federal Circuit." 16

\section{B. Factual Background and Procedural History}

Click-to-Call, owner of U.S. Patent No. 5,818,836 (the " "836 patent”), sued Thryv in 2001 for patent infringement. ${ }^{17}$ That lawsuit resulted in a voluntary dismissal without prejudice. ${ }^{18}$

In 2013, Thryv sought IPR on the '836 patent. ${ }^{19}$ Click-to-Call opposed the petition as being untimely under $\S 315(\mathrm{~b})$, as Thryv filed the petition more than one year after the 2001 complaint. ${ }^{20}$ The Board disagreed, asserting that "a complaint dismissed without prejudice does not trigger $\S 315(\mathrm{~b})$ 's one-year [clock]." ${ }^{21}$ The Board subsequently instituted IPR, which resulted in a final written decision rejecting Click-to-Call's $\S 315(\mathrm{~b})$ untimeliness argument and cancelling thirteen of the patent's claims. ${ }^{22}$

Click-to-Call appealed to the Federal Circuit, who dismissed the appeal on determination that $\S 314(\mathrm{~d})$ precludes jurisdiction over appeals based on $\S$ 315(b). ${ }^{23}$ Citing the Supreme Court's decision in Cuozzo Speed Technologies, $L L C$ v. Lee, ${ }^{24}$ the Supreme Court then "granted certiorari, vacated the judgment,

11. Id. (citing Cuozzo Speed Techs., LLC v. Lee, 136 S. Ct. 2131, 2141 (2016)).

12. Id. at 1370 .

13. 35 U.S.C. $\$ 314(a)$ (2019).

14. Thryv, 140 S. Ct. at 1370 (citing 35 U.S.C. $\$ 315$ (b)).

15. Id. (quoting 35 U.S.C. $\S 314(\mathrm{~d})$ ).

16. Id. at 1371 (quoting 35 U.S.C. $\S 319$ ).

17. $I d$.

18. Id.

19. Id.

20. Id.

21. $I d$.

22. $I d$.

23. Id. at 1371-72.

24. Cuozzo Speed Techs., LLC v. Lee, 136 S. Ct. 2131 (2016). 
and remanded." ${ }^{25}$ On remand, the Federal Circuit dismissed the appeal on the same grounds. ${ }^{26}$

Following the second dismissal, "the en banc Federal Circuit held that 'timebar determinations under $\S 315(\mathrm{~b})$ are appealable' notwithstanding $\S 314(\mathrm{~d}) .{ }^{21}$ In light of this decision, the Federal Circuit reheard Thryv and held that the IPR was untimely because the 2001 complaint started the $\S 315$ (b)'s one-year clock, even though the complaint was dismissed without prejudice. ${ }^{28}$ The Supreme Court subsequently granted certiorari to resolve the judicial review issue. ${ }^{29}$

\section{Justice Ginsburg's Opinion of the Court}

IPR institution decisions are generally not appealable pursuant to 35 U.S.C. $\S 314(\mathrm{~d}) .^{30}$ The Court affirmed this in Cuozzo. ${ }^{31}$ More specifically, the Court held that $\S 314(\mathrm{~d})$ bars appeals "where the grounds for attacking the decision to institute [IPR] consist of questions that are closely tied to the application and interpretation of statutes related to the [institution] decision. ${ }^{" 32}$ Applying that standard in Cuozzo, the Court rejected the appeal of the institution decision on the grounds that the petition did not challenge the claims "with particularity," as $\S$ 312(a)(3) requires, finding this to be closely tied to the Board's institution decision. $^{33}$

In this case, the Court likewise determined that $\S 315(\mathrm{~b})$ 's time limit is closely tied to the institution decision. Specifically, the Court reasoned that the decision to institute must consider whether the petition is timely. ${ }^{34}$ Under Cuozzo and $\S 314(\mathrm{~d})$, the appeal of an institution decision on the basis that the IPR was untimely is thereby prohibited. ${ }^{35}$ In further support of this conclusion, Justice Ginsburg leaned on the policy behind the AIA. ${ }^{36}$ Congress created IPR "to weed out bad patent claims efficiently." ${ }^{37}$ Allowing appeals based on $\S 315(\mathrm{~b})$ would conflict with that objective by allowing patent owners who lost claims in the IPR to appeal the institution decision, only for the Federal Circuit to undo the Board's decision canceling the bad claims. ${ }^{38}$ This would be inefficient and, potentially,

25. Thryv, 140 S. Ct. at 1372.

26. Id.

27. Id. (quoting Wi-Fi One, LLC v. Broadcom Corp., 878 F.3d 1364, 1367 (Fed. Cir. 2018)).

28. Id.

29. $I d$.

30. Id. at 1373 .

31. Id.

32. Id. (citing Cuozzo Speed Techs., LLC v. Lee, 136 S. Ct. 2131, 2141 (2016)).

33. Id.

34. $I d$.

35. $I d$.

36. Id. at 1374.

37. Id. (citing Cuozzo, 136 S. Ct. at 2139-40).

38. Id. (citing Cuozzo, 136 S. Ct. at 2139-40). 
allow bad patents to remain enforceable. ${ }^{39}$

The Court rejected Click-to-Call's argument that the $\S 314(\mathrm{~d})$ bar to institution decision appeals under this section applied only to $\S 314(\mathrm{a})$ 's determination whether the petitioner has a reasonable likelihood of prevailing. ${ }^{40}$ The Court reiterated that $\S 314(\mathrm{~d})$ 's bar on appeals extends to "the entire determination 'whether to institute an inter partes review."'41 The decision whether to institute under $\S 314$ must take other provisions into account, such as $\S 312(a)(3)$ 's particularity requirement at issue in Cuozzo and $\S 315(\mathrm{~b})$ 's timeliness requirement. ${ }^{42}$ If Congress wanted to limit the ban on appeals to $\S 314$ issues, Congress could have specified the determination under $\S 314$ or under $\S$ 314(a), rather than generally saying the determination "under this section." 43

\section{Justice Gorsuch's Dissent}

Justice Gorsuch, joined by Justice Sotomayor, dissented..$^{44}$ In dissent, Justice Gorsuch was troubled by how the majority's reading would give the Board the ability to exceed their statutory authority, without the ability of the parties to do anything about it. ${ }^{45}$

Justice Gorsuch also disagreed with the majority's statutory interpretation, asking how the institution decision "under this section" described in $\S 314(\mathrm{~d})$ could refer to anything outside of $\S 314$ and the institution decision described in $\S 314\left(\right.$ a) ${ }^{46}$ This stretched argument for including $\S 315$ (b) inside of $\S 314(d)$ 's bar of appeals should also fall to the presumption of judicial review of administrative action. ${ }^{47}$ Justice Gorsuch noted that this case continues the trend started in Oil States Energy Services, LLC v. Greene's Energy Group, $L L C,{ }^{48}$ which limited judicial review over executive agency decisions. ${ }^{49}$

In Justices Gorsuch's view, precedent did not require this result. ${ }^{50}$ Cuozzo addressed "little more than a challenge to the Patent Office's conclusion under $\S$ 314(a)." ${ }^{" 51}$ Cuozzo did not address $\S 315$ (b) or declare $\S 315$ (b) to be close enough to the institution decision to preclude judicial review. ${ }^{52}$

\section{Id.}

40. Id. at 1375 .

41. Id. (quoting 35 U.S.C. § 314(d) (2019)).

42. Id.

43. Id. at 1375-76 (quoting 35 U.S.C. $§ 314(d)$ ).

44. Id. at 1378 (Gorsuch, J., dissenting).

45. Id. at 1380 .

46. Id. at $1380-83$.

47. Id. at 1383-85.

48. Oil States Energy Servs., LLC v. Greene's Energy Grp., LLC, 138 S. Ct. 1365 (2018).

49. Thryv, $140 \mathrm{~S}$. Ct. at 1387-89.

50. Id. at $1385-87$.

51. Id. at 1386 (citing Cuozzo Speed Techs., LLC v. Lee, 136 S. Ct. 2131, 2142 (2016)).

52. Id. 


\section{DAMAGES FOR WILLFUL TRADEMARK INFRINGEMENT: ROMAG FASTENERS, INC. V. FOSSIL, INC.}

In Romag Fasteners, Inc. v. Fossil, Inc., the Supreme Court addressed the question of whether a finding of willfulness is a prerequisite for an award of profits in a trademark suit. ${ }^{53}$ The decision resolved a circuit split in which some federal appeals courts required a willfulness finding for disgorgement of profits, while others did not. ${ }^{54}$ Justice Gorsuch authored the opinion of the court, focusing on the text of the Lanham Act and holding that a finding of willfulness is not required for an award of disgorgement of profits in a trademark case. ${ }^{55}$

Romag makes magnetic snap fasteners used in accessories, including luxury handbags ${ }^{56}$ Fossil manufactures leather goods including handbags. ${ }^{57}$ Romag and Fossil had an agreement for the use of Romag's fasteners in Fossil handbags. ${ }^{58}$ Romag discovered that certain Fossil factories were making handbags that included counterfeit fasteners purporting to be from Romag and that Fossil was not taking adequate steps to prevent this from happening. ${ }^{59}$ Romag then brought suit against Fossil in federal district court for trademark infringement pursuant to 15 U.S.C. $\S 1125(a) .{ }^{60}$

The jury found that Fossil had infringed Romag's trademarks; however, it determined that the infringement was not willful. ${ }^{61}$ Due to this finding, the court concluded that Romag was not entitled to a disgorgement of Fossil's profits for handbags containing the counterfeit fasteners, based on Second Circuit precedent. ${ }^{62}$ The Federal Circuit affirmed the district court's holding. ${ }^{63}$

On writ of certiorari to the Federal Circuit, the Supreme Court addressed the circuit split. ${ }^{64}$ Justice Gorsuch authored the unanimous opinion of the court, holding that a finding of willfulness is not a prerequisite for disgorgement of a trademark infringer's profits under Section 35 of the Lanham Act, 15 U.S.C. $\S$ 1117(a). ${ }^{65}$ The court focused on the plain language of the Lanham Act, writing that "[a] plaintiff in a trademark infringement suit is not required to show that a defendant willfully infringed the plaintiff's trademark as a precondition to a profits award." $"$ Indeed, the court concluded, "[t]he Lanham Act provision

53. Romag Fasteners, Inc. v. Fossil, Inc., 140 S. Ct. 1492, 1494 (2020).

54. Id.

55. Id. at 1493.

56. Id. at 1494.

57. Id.

58. Id.

59. Id.

60. Id. at 1493 .

61. Id. at 1494 .

62. Id. at 1493 .

63. Id. at 1492 .

64. Id. at 1493

65. Id.

66. Id. 
governing remedies for trademark violations . . . has never required such a showing. Reading words into a statute should be avoided, especially when they are included elsewhere in the very same statute."${ }^{167}$

\section{COPYRIGHTABILITY OF CODE ANNOTATIONS: GEORGIA V. PUBLIC.RESOURCE.ORG, INC.}

On April 27, 2020, a divided U.S. Supreme Court ruled that state legislatorauthored annotations to the official state code are not copyrightable. ${ }^{68}$ According to this opinion, the government edicts doctrine provides that the work judges and legislators perform in the course of their duties is not copyrightable. ${ }^{69}$ Because an adjunct of the Georgia Legislature prepared the annotated code, no copyright could vest in that work. ${ }^{70}$

\section{A. Copyright Act Background}

Copyright protection vests "original works of authorship." 71 Thus, for a work to be protected by copyright, it must be created by an "author" who is eligible to obtain copyright protection..$^{72}$ By statute, works created by "an officer or employee of the United States Government as part of that person's official duties" are not eligible for copyright protection. ${ }^{73}$ The government edicts doctrine subjects state government actors to the same standard. ${ }^{74}$

\section{B. Factual and Procedural Background}

Georgia has one official code: the Official Code of Georgia Annotated ("OCGA"). ${ }^{75}$ It includes the statutes, and below them, annotations to the statutes. ${ }^{76}$ The annotations summarize decisions and opinions on each statute, along with the origins of statutory language. ${ }^{77}$

The Code Revision Commission (the "Commission") assembles the OCGA. ${ }^{78}$ A majority of the Commission's fifteen members must be Georgian Legislators. ${ }^{79}$ The office is staffed by the Legislative Counsel, which serves the legislative

67. Id.

68. Georgia v. Public.Resource.Org, Inc., 140 S. Ct. 1498, 1503-04 (2020).

69. Id. at 1508 .

70. Id. at 1513

71. Id. at 1503 (citing 17 U.S.C. § 102(a) (2019)).

72. Id. at 1504 .

73. Id. at 1509 (citing 17 U.S.C. $\S \S 101,105$ ).

74. Id. at 1509-10.

75. Id. at 1504 .

76. $I d$.

77. $I d$.

78. $I d$.

79. Id. 
branch of government. ${ }^{80}$ After the annotations are drafted, the legislature votes to enact the laws, merge the statutes with the annotations, and publish the laws and annotations together. ${ }^{81}$ The OCGA is assembled by a division of LexisNexis Group, under a work-for-hire agreement with the Commission, whereby copyright vests in "the State of Georgia, acting through the Commission." 2 Thereafter, Lexis can exclusively distribute the OCGA. ${ }^{83}$

Public.Resource.Org ("PRO"), a non-profit dedicated to making public access to government and legal materials easier, posted a digital version of the OCGA online, where the public could download it for free. ${ }^{84}$ The Commission sued PRO for copyright infringement, asserting that it had copyright in the annotations to the code. ${ }^{85}$ PRO countered by seeking a declaration that the entire OCGA was in the public domain. ${ }^{86}$

The district court granted summary judgment to the Commission and found that the annotations were eligible for copyright protection because they were "not enacted into law" and they lacked "the force of law." ${ }^{87}$ The Eleventh Circuit reversed, finding that the works fell within the government edicts doctrine and were thus "in the public domain." 88 The Supreme Court granted certiorari and affirmed the outcome of the Eleventh Circuit, but for different reasons. ${ }^{89}$

\section{Chief Justice Roberts's Opinion of the Court}

Three nineteenth century cases form the basis of the government edicts doctrine. ${ }^{90}$ The first case, Wheaton $v$. Peters, ${ }^{91}$ held that no judge or court reporter can have copyright in the judicial opinions. ${ }^{92}$ The second case, Banks $v$. Manchester, ${ }^{93}$ held that judges, writing in their judicial capacity, cannot be regarded as authors under the Copyright Act, so no copyright can vest in "whatever work they perform in their capacity as judges," including binding opinions and non-binding works, such as headnotes and syllabi. ${ }^{94}$ The third case,

80. Id.

81. Id. at $1504-05$.

82. Id. at 1505 .

83. Id.

84. Id.

85. Id.

86. Id.

87. Id. (quoting Code Revision Comm'n v. Public.Resource.Org, Inc., 244 F. Supp. 3d 1350, 1356 (N.D. Ga. 2017)).

88. Id. (quoting Code Revision Comm'n v. Public.Resource.Org, Inc., 906 F.3d 1229, 1239 (11th Cir. 2018)).

89. Id. at $1506,1519$.

90. Id. at $1506-08$.

91. Wheaton v. Peters, 33 U.S. 591 (1834).

92. Public.Resource.Org, 140 S. Ct. at 1506 (citing Wheaton, 33 U.S. at 668).

93. Banks v. Manchester, 128 U.S. 244 (1888).

94. Public.Resource.Org, 140 S. Ct. at 1506-07 (quoting Banks, 128 U.S. at 253). 
Callaghan v. Myers,${ }^{95}$ held that if the reporter of judicial decisions creates headnotes or syllabi for the cases they report, the reporter can have copyright in those aspects because the author does not have the "authority to speak with the force of law." ${ }^{" 96}$ In short, these cases stand for the proposition that the law, which binds every citizen, is free for publication to all..$^{97}$ Thus the law, in the form of statutes and judicial opinions, cannot be copyrighted..$^{98}$ With that backdrop, the court extended this reasoning to legislators and their work in the legislature. ${ }^{99}$

Courts evaluate the government edicts doctrine under the following standard: no authorship exists, under the Copyright Act, in works which are "(1) created by judges and legislators (2) in the course of their judicial and legislative duties." 100 At step one, the Court found that the Commission is the author and their work is the work of Georgia's legislature. ${ }^{101}$ Under the work-for-hire doctrine, the Commission is the author of the work it asked Lexis to prepare. ${ }^{102}$

The Court found the Commission to be the legislature by considering several facts. ${ }^{103}$ Although " $[t]$ he Commission is not identical to the Georgia Legislature, [it] functions as an arm of it for the purpose of producing the annotations." 104 The legislature created the Commission, and many members of the commission are legislators. ${ }^{105}$ The Commission receives funding and staff from the legislature, and the annotations must be approved by the legislature before being published with the statutory text as the official code. ${ }^{106}$ Georgia's Supreme Court held that the Commission's work "is within the sphere of legislative authority." 107 The Commission even brought suit "on behalf of and for the benefit of the Georgia Legislature." 108

At step two, the Court found that the Commission created the annotations in the course of their legislative duties. ${ }^{109}$ The Commission's creation of the OCGA is an "act of legislative authority." ${ }^{110}$ Even though the annotations are not enacted into law, the annotations do not need to have the force of law. ${ }^{11}$ The annotations

95. Callaghan v. Myers, 128 U.S. 617 (1888).

96. Public.Resource.Org, 140 S. Ct. at 1507.

97. Id. at 1506-07 (citing Banks, 128 U.S. at 253).

98. Id. at 1508 .

99. Id. at 1507.

100. Id. at 1508 .

101. Id.

102. Id. (citing 17 U.S.C. $\$ 201(b)(2019)$ ).

103. Id. at 1508-09.

104. Id. at 1508 .

105. Id.

106. Id.

107. Id. (quoting Harrison Co. v. Code Revision Comm'n, 260 S.E.2d 30, 34 (Ga. 1979)).

108. Id. at 1508-09 (citation and internal quotation marks omitted).

109. Id. at 1509 .

110. Id. (internal quotation marks omitted).

111. Id.; see Callaghan v. Myers, 128 U.S. 617, 647 (1888). 
are made by legislators acting in their capacity as legislators. ${ }^{112}$ Thus, the Commission cannot be an author and there is no copyright in the annotations. ${ }^{113}$

The Court did not find any other arguments advanced by the Commission to be persuasive. Although annotations are listed as being copyrightable under $\S$ 101, they must represent an original work of authorship made by an eligible author. ${ }^{114}$ Further, the fact that Federal Employees cannot obtain copyright in their works created as part of their official duties does not result in the negative inference for states that there can be copyright in works prepared by state employees in the course of all of their official duties. ${ }^{115}$ The broad federal rule does not displace the narrow government edicts doctrine, and states can still assert copyright in works created by their employees, such as copyright in works prepared by state university professors. ${ }^{116}$

\section{Justice Thomas's Dissent}

Justices Thomas, Alito, and Breyer (in part) dissented. ${ }^{117}$ In his dissenting opinion, Justice Thomas reasoned that if annotations included with judicial opinions can be copyrighted, there is no reason that annotations included with statutes or regulations should not be copyrightable. ${ }^{118}$ Justice Thomas also questioned the majority's use of "author" to exclude the legislature from creating copyrightable works. ${ }^{119}$ Unlike judges who do not need the encouragement of the exclusive grant of copyright, those creating annotations may need the encouragement of the exclusive copyright grant. ${ }^{120}$ Justice Thomas found textual support in the Copyright Act itself, which does not define "author" nor say anything about authorship and works created by the government. ${ }^{121}$

\section{E. Justice Ginsburg's Dissent}

Justices Ginsburg and Breyer dissented by disagreeing with the majority's analysis under the two-part government edict test. ${ }^{122}$ Honing in on the second part of the test, Justice Ginsburg noted that the Legislature's duty is to make the law. ${ }^{123}$ Justice Ginsburg explained that the Commission's creation of the OCGA does not make the law, and is thus not part of the legislative process because the

112. Public.Resource.Org, 140 S. Ct. at 1509; see Callaghan, 128 U.S. at 253.

113. Public.Resource.Org, 140 S. Ct. at 1509.

114. Id. (citing 17 U.S.C. $§ 101$ (2019)).

115. Id. at 1509-10.

116. Id. at 1510 .

117. Id. at 1513-22 (Thomas, J., dissenting).

118. Id. at 1515 .

119. Id.

120. Id. at $1515-17$.

121. Id. at 1518; 17 U.S.C. $\S 101$ (2021).

122. Public.Resource.Org, 140 S. Ct. at 1522-23 (Ginsburg, J., dissenting).

123. Id. at 1523 . 
annotations are created only after the law is made. ${ }^{124}$ In other words, the annotations describe the law, rather than proscribe the law; and the annotations are "given for the purpose of convenient reference," rather than to assist the legislature in determining what laws to enact. ${ }^{125}$

\section{TRADEMARK PROTECTION FOR “.COM” MARKS: USPTO V. BOOKING.COM}

In U.S. Patent \& Trademark Office v. Booking.com B.V., the Supreme Court rejected the USPTO's argument that the addition of ".com" to a generic term is per se insufficient to transform the mark into a non-generic and therefore potentially protectable trademark. ${ }^{126}$ Instead, the Court concluded that whether a ".com" term is generic must be determined by looking at the mark as a whole and determining whether it signifies to a class of consumers a category of goods and services. ${ }^{127}$

\section{A. Background}

Generic names - those that simply describe a class of goods and/or services - are not eligible for federal trademark protection. ${ }^{128}$ Thus, the USPTO denies entry into the federal principal trademark register where the mark in question is merely "the generic name for the goods or services." 129 Trademark protection is understood on a scale between the most arbitrary, fanciful, and suggestive marks on the one hand, which are inherently distinctive and more easily protectable as trademarks, and merely generic terms on the other end of the spectrum, which are not protectable and are available to anyone who might want to use them to describe the applicable category of goods or services. ${ }^{130}$ In between these categories on the scale are marks that are "merely" descriptive of the goods and services, which may be registered on the principal register if an applicant shows that they have acquired distinctiveness in the minds of the relevant consumers. ${ }^{131}$

Booking.com is an online travel company that allows users to make a variety of travel-related reservations, such as reservations for hotels and rental cars. ${ }^{132}$ Its website is, aptly, "Booking.com."133 The company sought federal trademark registration for several marks containing the phrase "booking.com," and received

rejections by the USPTO on the basis that "booking.com" is not registerable as

124. Id.

125. Id. at 1523-24 (quoting OCGA § 1-1-7 (2020)).

126. U.S. Patent \& Trademark Office v. Booking.com B.V., 140 S. Ct. 2298, 2301 (2020).

127. Id.

128. Id. at 2302-03.

129. Id. at 2303 .

130. Id. at 2302-03.

131. Id. at 2308 .

132. Id. at 2303 .

133. Id. 
a trademark because it is generic. ${ }^{134}$ Specifically, the USPTO reasoned that "booking" is merely a generic term for "making travel registrations," and ".com" merely "signifies a commercial website." ${ }^{135}$ Booking.com disagreed. ${ }^{136}$

After exhausting available avenues at the USPTO, it sought review of the USPTO's registration refusal by the U.S. District Court for the Eastern District of Virginia. ${ }^{137}$ This allowed Booking.com to submit new evidence to the court of consumer perception. ${ }^{138}$ The District Court relied on Booking.com's evidence of consumer perception to conclude that "Booking.com" is not generic. ${ }^{139}$ Instead, the court concluded that "BOOKING.COM does not refer to a genus, rather it is descriptive of services involving 'booking' available at that domain name." ${ }^{\prime 40}$ The USPTO appealed to the Court of Appeals for the Fourth Circuit, which affirmed the district court's judgment. ${ }^{141}$ On petition for writ of certiorari, the Supreme Court granted certiorari and affirmed the Fourth Circuit's decision. ${ }^{142}$

\section{B. Justice Ginsburg's Opinion of the Court}

Justice Ginsburg authored the opinion of the Court, rejecting a rule that a "generic.com" name is per se generic. The USPTO urged the Supreme Court to adopt a rule that when an applicant sought to register a mark that included a generic term coupled with ".com," the addition of ".com" is insufficient per se to transform that mark into something other than a generic term. ${ }^{143}$ The Court disagreed. Instead, the court held that " $[\mathrm{w}]$ hether any given 'generic.com' term is generic . . . depends on whether consumers in fact perceive that term as the name of a class or, instead, as a term capable of distinguishing among members of the class." 144

The Court began by pointing out the definition of a generic mark, namely a " "class' of goods or services, rather than any particular feature or exemplification of the class." 145 On that ground, the court noted that "whether 'Booking.com' is generic turns on whether that term, taken as a whole, signifies to consumers the class of online hotel-reservation services." ${ }^{146}$ If that were so, then consumers might consider other online booking sites (e.g., Travelocity) to be a

134. $I d$.

135. Id.

136. Id.

137. Id.

138. Id.

139. Id. (citing Booking.com B.V. v. Matal, 278 F. Supp. 3d 891, 918 (E.D. Va. 2017)).

140. Id. (quoting Matal, 278 F. Supp. 3d at 918).

141. Id. at 2304 .

142. Id.

143. Id. at 2305 .

144. Id. at 2307.

145. Id. at 2304.

146. Id. 
"booking.com." ${ }^{147}$ But, the court pointed out, there was no dispute about the fact that consumers did not, in fact, hold this perception. ${ }^{148}$ According to the Court, this fact alone would have been sufficient to resolve the case. ${ }^{149}$

Nevertheless, the majority opinion continued to point out that it saw no basis for a per se rule of genericness of "generic.com" names in either trademark law or the USPTO's trademark examination procedures. Concerning trademark law, the Court focused on a "bedrock principle" of the Lanham Act that "whether a term is generic depends on its meaning to consumers." "And as to the USPTO's examination practices, the court pointed to existing ".com" registrations which the USPTO had allowed on the principal register and would be at risk of cancellation if the USPTO's blanket genericness rule were allowed. ${ }^{151}$

\section{Concurring and Dissenting Opinions}

Justices Sotomayor and Breyer authored separate opinions. Justice Breyer's dissent focused on the fact that, in his opinion, a term such as "booking.com" does nothing more than "informs the consumer of the basic nature of its business." 152 He highlighted trademark principles including the Supreme Court's decision in Goodyear's Rubber Manufacturing. Co. v. Goodyear Rubber Co. ${ }^{153}$ in which the Court held that adding a corporate designation such as "Company" to a generic name does not create a protectable compound name. ${ }^{154}$ Justice Breyer would have applied this same logic to append ".com" to a generic name. ${ }^{155}$ The majority opinion rebutted this argument by interpreting Goodyear as standing for the proposition it adopted - the mark must be considered as a whole, without a per se rule about the effect of individual elements. ${ }^{156}$

Justice Breyer also opined that sound trademark policy favors the predictability of a bright-line rule regarding the effect of appending ".com" to a mark. ${ }^{157} \mathrm{He}$ concluded by expressing concern for the anticompetitive consequences in the online marketplace of allowing registration of otherwise generic marks merely by appending a ".com," which he suggested could lead, if taken to its extreme, to a result where a small number of companies would possess control on the Internet over entire categories of goods and services. ${ }^{158}$

Justice Sotomayor concurred to point out that (1) surveys designed to show

147. Id. at 2304-05.

148. Id. at 2305.

149. Id.

150. Id. at 2306 .

151. Id. at 2305 .

152. Id. at 2309 (Breyer, J., dissenting).

153. Goodyear's Rubber Mfg. Co. v. Goodyear Rubber Co., 128 U.S. 598 (1888).

154. Booking.com, 140 S. Ct. at 2310-11 (citing Goodyear's Rubber Mfg., 128 U.S. at 602-03).

155. Id. at 2311 .

156. Id. at 2305-06 (majority opinion).

157. Id. at 2314-15 (Breyer, J., dissenting).

158. Id. 
consumer perception are not the only source of authority for determining whether a mark is generic, and other sources of relevant evidence could include "dictionaries, usage by consumers and competitors, and any other source of evidence bearing on how consumers perceive a term's meaning"; and (2) although not before the court, she noted that dictionary and usage evidence might have supported a proper conclusion by the USPTO that the entire "booking.com" mark was generic. ${ }^{159}$

\section{VENUE IN PATENT LitigATION (SECOND TIME IS THE CHARM AS FEDERAL CIRCUIT FINDS NO VENUE IN THE EASTERN DISTRICT OF TEXAS FOR GOOGLE SERVER RACKS): IN RE GOOGLE LLC}

In February 2020, the Federal Circuit granted Google's petition for writ of mandamus to resolve district courts' conflicting applications of the patent venue statute. ${ }^{160}$ Although the Federal Circuit had denied Google's previous writ of mandamus, filed more than one year before the instant writ, district courts had reached different conclusions on the patent venue statute in the interim, warranting the grant of the instant petition. ${ }^{161}$ Elaborating further on the requirements for venue articulated in In re Cray, Inc., ${ }^{162}$ the Court held that the required "place" of business need only be a physical location in the district and the defendant need not own or lease any real property to meet this requirement. ${ }^{163}$ There must also be an employee or agent of the defendant conducting the defendant's business in the district. ${ }^{164}$ Applied to this case, the server racks Google used to cache local Google data constituted a "place" under the Cray test, but the ISPs who installed Google's servers, provided internet access, and performed maintenance tasks on the server racks were not Google's agents. ${ }^{165}$ Further, agents performing maintenance activities alone do not qualify as carrying out the regular business of the defendant. ${ }^{166}$ Thus, venue was not appropriate in the Eastern District of Texas. ${ }^{167}$

\section{A. Patent Venue and Service Background}

The patent venue statute, 28 U.S.C. $\S 1400(b)$, provides that "[a]ny civil action for patent infringement may be brought in the judicial district where the defendant resides, or where the defendant has committed acts of infringement and

159. Id. at 2309 (Sotomayor, J., concurring).

160. In re Google LLC, 949 F.3d 1338, 1343 (Fed. Cir. 2020).

161. Id. at 1342 (citing In re Google LLC, No. 2018-152, 2018 WL 5536478, at *2, 2018 U.S. App. LEXIS 31000, at *6 (Fed. Cir. Oct. 29, 2018); In re Google LLC, 914 F.3d 1377, 1380 (Fed. Cir. 2019)).

162. In re Cray, Inc., 871 F.3d 1355, 1360 (Fed. Cir. 2017).

163. Google, 949 F.3d at 1343.

164. Id. at 1344 .

165. Id. at 1345-47.

166. Id. at 1346.

167. Id. at 1347. 
has a regular and established place of business." 168 The Supreme Court articulated in TC Heartland LLC v. Kraft Foods Group Brands LLC "that a domestic corporation 'resides' only in its State of incorporation for purposes of the patent venue statute." 169 The Federal Circuit elaborated on the "regular and established place of business" in Cray. ${ }^{170}$ Under Cray, the "regular and established place of business" must be: (1) "a physical place in the district"; (2) "regular and established"; and (3) "the place of the defendant." 171

Originally, the patent venue and patent service statutes were in the same statutory section. ${ }^{172}$ The service statute was the second sentence of the statute, following the venue provision. ${ }^{173}$ Now codified at 28 U.S.C. $\S 1694$, the service statute reads:

If such suit is brought in a district of which the defendant is not an inhabitant, but in which such defendant has a regular and established place of business, service of process, summons, or subpoena upon the defendant may be made by service upon the agent or agents engaged in conducting such business in the district in which the suit is brought. ${ }^{174}$

\section{B. Factual Background}

At the time of the complaint, Google maintained Google Global Cache ("GGC") servers in the Eastern District of Texas, which function as local caches for Google's data. ${ }^{175}$ Google did not have any employees in the District, but rather, Google contracted with two internet service providers ("ISPs") in the District to host and perform various tasks on the GGC servers in the ISPs' data centers. ${ }^{176}$

The ISPs contracted to perform three tasks for Google. ${ }^{177}$ They contracted to set up and install the GGC servers on their server racks. ${ }^{178}$ The ISPs contracted to connect the GGC servers to the internet. ${ }^{179}$ Finally, the ISPs contracted to perform maintenance tasks on the GGC servers with the prior written consent of Google. ${ }^{180}$ The ISP employees were not to perform any other activities relating

168. 28 U.S.C. $§ 1400($ b) (2019) (emphasis added).

169. TC Heartland LLC v. Kraft Foods Grp. Brands LLC, 137 S. Ct. 1514, 1517 (2017).

170. Google, 949 F.3d at 1340 (citing In re Cray, Inc., 871 F.3d 1355, 1360 (Fed. Cir. 2017)).

171. Id. (quoting Cray, 871 F.3d at 1360).

172. Id. at 1344 .

173. Id.

174. Id. (emphasis added) (quoting Act of Mar. 3, 1897, ch. 395, 29 Stat. 695).

175. Id. at 1340.

176. Id.

177. Id. at 1345 .

178. Id. at 1340,1346 .

179. Id. at $1340,1345-46$.

180. Id. at $1340-41,1346$. 
to the servers without Google's prior permission. ${ }^{181}$

\section{Procedural History}

Super Interconnect Technologies LLC ("SIT") sued Google in the Eastern District of Texas for patent infringement. ${ }^{182}$ Google moved to dismiss for improper venue under 28 U.S.C. $\S 1400$ (b) and Federal Rule of Civil Procedure 12(b)(3) ${ }^{183}$ SIT contended that venue was proper because Google provides video and advertising services to residents of the District, and the GGC servers are located in the district. ${ }^{184}$ The district court denied Google's motion and found that the GGC servers in the district were Google's "regular and established place of business," thus satisfying the venue test set out in Cray ${ }^{185}$ Google then petitioned the Federal Circuit for a writ of mandamus directing the district court to dismiss for lack of venue. ${ }^{186}$

\section{Judge Dyk's Opinion of the Court}

Judge Dyk began by analyzing whether the requirements for issuance of a writ were met. ${ }^{187}$ For a writ to issue, "(1) the petitioner '[must] have no other adequate means to attain ... relief,' (2) the petitioner must show that the right to mandamus is 'clear and indisputable,' and (3) the court must be 'satisfied that the writ is appropriate under the circumstances." 188 The Supreme Court has held that "the requirements for mandamus are satisfied when the district court's decision involves 'basic' and 'undecided' legal questions." 189

This petition contained undecided legal questions. ${ }^{190}$ Since the denial of Google's previous writ of mandamus, which contained "identical facts" to the instant writ, the district courts have adopted conflicting views on the requirements of venue. ${ }^{191}$ Some district courts had held that a server rack operated by the defendant's agents could be a regular and established place of business, while other courts have held that server racks cannot. ${ }^{192}$ The Federal Circuit had also not

181. Id. at 1340 .

182. Id. at 1339.

183. Id. at 1341 .

184. Id. at 1340 .

185. Id. at 1341. The district court also relied upon it's the prior decision in Seven Networks, $L L C$ v. Google LLC, 315 F. Supp. 3d 933 (E.D. Tex. 2018), to find venue appropriate for Google in the Eastern District.

186. Id.

187. Id.

188. Id. (quoting Cheney v. U.S. Dist. Court for D.C., 542 U.S. 367, 380-81 (2004) (alteration in original) (internal quotation marks and citations omitted)).

189. Id. (citing Schlagenhauf v. Holder, 379 U.S. 104, 110 (1964)).

190. Id. at 1343 .

191. Id. at 1342 .

192. Id. at 1342 n.2 (Compare, e.g., Tinnus Enters., LLC v. Telebrands Corp., No. 6:17-CV00170, 2018 WL 4560742, at *5, 2018 U.S. Dist. LEXIS 79068, at*14 (E.D. Tex. Mar. 9, 2018) 
issued guidance on whether the place of business required an employee or agent of the defendant. ${ }^{193}$ Since these issues are basic and fundamental, and because these issues would not likely be preserved through the regular appellate process after trial, the Federal Circuit found that granting the writ of mandamus was now appropriate. ${ }^{194}$

Judge Dyk then addressed the requirements for venue under Cray. ${ }^{195}$ The three venue requirements are "(1) there must be a physical place in the district; (2) it must be a regular and established place of business; and (3) it must be the place of the defendant." 196

The court rejected Google's argument that the physical "place of business" required the characteristics of an ownership or a leasehold interest in real property. ${ }^{197}$ The place must only be a "physical, geographical location in the district from which the business of the defendants is carried out" that the defendant can possess or control. ${ }^{198}$ Because the place must be a geographical location, virtual spaces cannot constitute a regular or established place of business. ${ }^{199}$ Here, the rack space occupied by the GGC servers is a "place" under $\S 1400(b) .{ }^{200}$ The GGC servers are in a fixed geographical location physically

(holding that "leased shelf space ... was a regular and established place of business where the defendant paid 'agents to monitor, clean, restock, and affix price signage"'), with CUPP Cybersecurity LLC v. Symantec Corp., No. 3:18-CV-01554, 2019 WL 1070869, 2019 U.S. Dist. LEXIS 37960 (N.D. Tex. Jan. 16, 2019) (finding “defendant's servers hosted [and] operated by a third party were not a regular and established place of business"), Pers. Audio, LLC v. Google, Inc., 280 F. Supp. 3d 922, 935 (E.D. Tex. 2017) ("holding that Google's GGC servers were not regular and established places of business"), and Automated Packaging Sys., Inc. v. Free-Flow Packaging Int'l, Inc., No. 5:14-cv-2022, 2018 WL 400326, 2018 U.S. Dist. LEXIS 5910 (N.D. Ohio Jan. 12, 2018) (holding that movable equipment cannot constitute "a physical, geographical location" for the purposes of patent venue)).

193. Id. at 1342 n.2, 1343 n.3 (See also Rensselaer Polytechnic Inst. v. Amazon.com, Inc., No. 1:18-cv-00549, 2019 WL 3755446, at*11, 2019 U.S. Dist. LEXIS 136436, at*34, *36 (N.D.N.Y. Aug. 7, 2019); CDx Diagnostic, Inc. v. U.S. Endoscopy Grp., Inc., No. 13-CV-5669, 2018 WL 2388534, at*3, 2018 U.S. Dist. LEXIS 87999, at*7 (S.D.N.Y. May 24, 2018) (holding that there was no regular and established place of business at defendant's storage unit because defendant had no agent or employee conducting business there); Peerless Network, Inc. v. Blitz Telecom Consulting, LLC, No. 17-CV-1725, 2018 WL 1478047, at*4, 2018 U.S. Dist. LEXIS 49628, at*9 (S.D.N.Y. Mar. 26, 2018) (requiring "some employee or agent of the defendant to be conducting business at the location in question" to constitute a regular and established place of business); Brief of Acushnet et al. as Amici Curiae in Support of Petitioner at 12 n.3, Google, 949 F.3d 1338 (No. 15) (collecting cases)).

194. Id. at 1342-43.

195. Id. at 1343.

196. Id. (quoting In re Cray, Inc., 871 F.3d 1355, 1360 (Fed. Cir. 2017)).

197. Id.

198. Id. (citing Cray, 871 F.3d at 1362).

199. Id.

200. Id. at 1343-44. 
located in the Eastern District of Texas. ${ }^{201}$ Thus, the leased shelf space may constitute a "place" even though the lease is not one of real property. ${ }^{202}$

However, the Federal Circuit agreed with Google's second argument, that the " "place of business' generally requires an employee or agent of the defendant to .. . conduct[ the defendant's] business at that place." ${ }^{203}$ This is "apparent" based on the service statute for patent cases. ${ }^{204}$ Because the venue and service statutes were once in the same section, the two now-separate sections must be read together. ${ }^{205}$ The venue provision gave district courts original jurisdiction over patent disputes where the defendant was an inhabitant of the district or had committed acts of infringement and had "a regular and established place of business" in the district. ${ }^{206}$ Where the defendant is not an inhabitant of the district but has a "regular and established place of business," service of process may be completed by serving the agents "engaged in conducting such business." Because both statutes contain the same language, they must be interpreted consistently, considering each statute in light of the other. ${ }^{208}$

The service statute assumes that the defendant has a regular and established place of business, within the meaning of the venue statute, only if the defendant has an agent engaging in such business. ${ }^{209}$ The service statute assumes the presence of the agent at the regular and established place of business, and thus the venue statute's regular and established place of business requirement also presumes the presence of an agent. ${ }^{210}$ The legislative history confirms this reading. ${ }^{211}$

The amendment to the venue statute in the AIA did not disavow the requirement of an agent or employee at the defendant's place of business, as SIT suggested. ${ }^{212}$ The AIA provides that "an automated teller machine" does not satisfy $\S 1400(\mathrm{~b})$ 's requirement of a regular and established place of business for patent infringement actions for covered business methods. ${ }^{213}$ The court saw no reason this amendment, which did not mention the employee or agent

201. Id. at 1343 .

202. Id. at $1343-44$.

203. Id. at 1344 .

204. Id. (citing 28 U.S.C. $§ 1694$ (2019)).

205. Id.

206. Id. (quoting Act of Mar. 3, 1897, ch. 395, 29 Stat. 695).

207. Id. (quoting Act of Mar. 3, 1897, ch. 395, 29 Stat. 695).

208. Id. (citing United States v. Tinklenberg, 563 U.S. 647, 664, (2011); United States v. Davis, 139 S. Ct. 2319, 2329 (2019)).

209. Id.

210. Id.

211. "[T]he 'main purpose' of the statute was to 'give original jurisdiction to the court where a permanent agency transacting the business is located." Id. at 1345 (emphasis omitted) (citing 29 CONG. ReC. 1900 (1897) (statement of Rep. Lacey)).

212. Id.

213. Id. (quoting America Invents Act, Pub. L. No. 112-29, § 18(c), 125 Stat. 284, 331 (2011)). 
requirement, should alter its analysis. ${ }^{214}$

The court subsequently reviewed whether Google was subject to venue in the Eastern District of Texas. Because Google had no employees in the District, the only way Google could be subject to venue there was if the ISPs who housed Google's servers were Google's agents conducting Google's business. ${ }^{215}$

The Court held that the ISPs were not Google's agents. ${ }^{216}$ The agency relationship requires: "the principal's right to direct or control the agent's actions, ... the manifestation of consent by the principal to the agent that the agent shall act on his behalf, and ... the consent by the agent to act."217

The ISPs performed three functions for Google. "First, the ISP[s] provide[] the GGC servers with network access." 218 Google had no right of control over how the ISPs provided network access, so for this task, the ISPs were not Google's agents. ${ }^{219}$

Second, the ISPs install the GGC servers. ${ }^{220}$ The ISPs must follow several directions to install the GGC servers. ${ }^{221}$ Although the installation activities may suggest an agency relationship, the court did not consider these activities to be "conducting Google's business within the meaning of the statute," as installing the servers is a one-time event. ${ }^{222}$

Finally, the ISPs were to perform basic maintenance activities on the GGC servers. ${ }^{223}$ " $[\mathrm{O}]$ nly with the [prior] specific and direct step-by-step instructions from Google" could the ISPs conduct these maintenance activities. ${ }^{224}$ Although this also suggests an agency relationship, the court held that these maintenance activities alone cannot be considered the conduct of Google's business. ${ }^{225}$ "Maintaining equipment is meaningfully different from . . . producing, storing, and furnishing" the business's offerings to customers, which were the activities Congress focused on when drafting the venue statute. ${ }^{226}$ There is no suggestion that maintenance activities, even as they existed in the late nineteenth century, conferred proper venue. ${ }^{227}$ The Supreme Court has also cautioned against a broad reading of the venue statute and the need for clear venue rules to avoid expense on this non-merits issue. ${ }^{228}$ To achieve this end and follow Congress's intent,

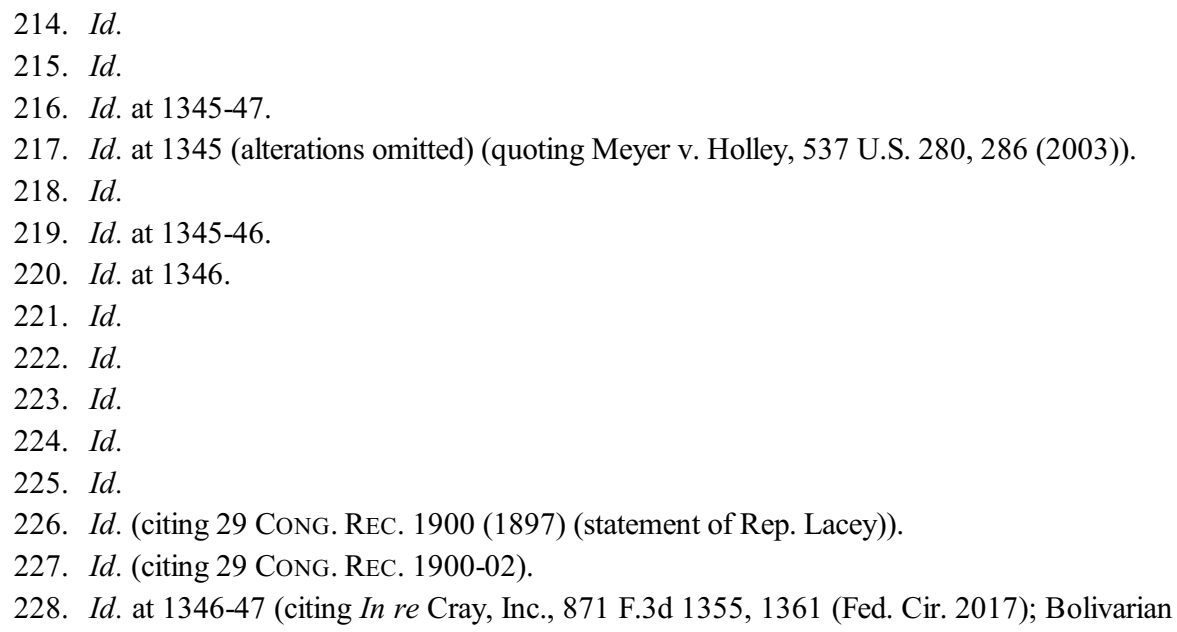


maintenance activities are not considered the regular conduct of a business for the purposes of venue. ${ }^{229}$

Judge Dyk wrote to limit the holding, stating that the Court is not suggesting that the "regular and established place of business" will always require the presence of a human employee or agent. ${ }^{230}$ A machine could serve as an "agent," but service upon machines with process would have to be possible under 28 U.S.C. $\S 1694 .^{231}$ Thus, the Federal Circuit concluded by ordering the case be dismissed or transferred to a proper venue. ${ }^{232}$

\section{E. Judge Wallach's Concurrence}

Judge Wallach joined the majority's order, but wrote separately to suggest that district courts investigate whether Google's end users may become Google's agents by voluntarily or involuntarily sharing information that Google's servers generate. ${ }^{233}$ A core aspect of Google's business model is the monetization of its users' behaviors on its website; therefore, Google's users may become Google's agents by sharing information because this activity furthers Google's business. ${ }^{234}$

\section{PATENT ELIGIBILITY OF ClAIMS THAT EXPRESS A NATURAL LAW AND THE "NOTHING MORE" TEST: AMERICAN AXLE \& MANUFACTURING, INC. V. NEAPCO HOLDINGS LLC}

In July 2020, an equally-divided Federal Circuit denied a request for en banc rehearing of the panel's decision in American Axle \& Manufacturing, Inc. v. Neapco Holdings $L L C$. $^{235}$ The judges concurring in the outcome asserted that the "nothing more" test is not new, as the Supreme Court first articulated the principle in O'Reilly v. Morse, ${ }^{236}$ and that the panel's ruling is consistent with precedent. ${ }^{237}$ The dissenters from the denial argued that the "nothing more" test is a new test, and the majority's application mischaracterizes the lessons in O'Reilly by expansively applying it. ${ }^{238}$ Further, the dissenters urged that the majority's application of the "nothing more" test makes patent eligibility more uncertain and is procedurally improper. ${ }^{239}$

Rep. Venez. v. Helmerich \& Payne Int'l Drilling Co., 137 S. Ct. 1312, 1321 (2017)).

229. Id. at 1347.

230. Id.

231. Id.

232. Id.

233. Id. at 1348 (Wallach, J., concurring).

234. Id.

235. Am. Axle \& Mfg., Inc. v. Neapco Holdings LLC, 966 F.3d 1347 (Fed. Cir. 2020). The active judges were divided six to six in their decision on whether to grant en banc rehearing. See id.

236. O'Reilly v. Morse, 56 U.S. 62 (1853).

237. Am. Axle, 966 F.3d at 1350, 1352-53 (Dyk and Chen, JJ., concurring).

238. Id. at 1361-62, 1366 (O'Malley, J., dissenting).

239. Id. at 1357-61, 1363-65 (Stoll, J., dissenting). 


\section{A. Factual Background}

American Axle and Manufacturing (AAM) holds U.S. Patent No. 7,774,911 (the "“911 patent"). ${ }^{240}$ This patent is directed to various methods of reducing vibrations in an automobile driveshaft assembly. ${ }^{241}$ On appeal, the panel discussed claims 1 and $22 .{ }^{242}$ Claim 1 is patent-eligible, while claim 22 and its related claims are not. ${ }^{223}$ The panel found claim 22 to assert nothing more than Hooke's Law, which describes the relationship between mass, stiffness, and frequency. ${ }^{244}$ Mathematically, Hooke's Law provides that "the applied force $F$ equals a constant $k$ times the displacement or change in length $x$, or $F=k x . " 245$ The value of $k$ depends on the type, dimensions, and shape of the material. ${ }^{246}$

\begin{tabular}{|c|c|}
\hline Claim 1 (eligible) & Claim 22 (ineligible) \\
\hline $\begin{array}{l}\text { A method for manufacturing a shaft assembly of } \\
\text { a driveline system, the driveline system further } \\
\text { including a first driveline component and a } \\
\text { second driveline component, the shaft assembly } \\
\text { being adapted to transmit torque between the } \\
\text { first driveline component and the second } \\
\text { driveline component, the method comprising: } \\
\text { providing a hollow shaft member; tuning at least } \\
\text { one liner to attenuate at least two types of } \\
\text { vibration transmitted through the shaft member; } \\
\text { and positioning the at least one liner within the } \\
\text { shaft member such that the at least one liner is } \\
\text { configured to damp shell mode vibrations in the } \\
\text { shaft member by an amount that is greater than } \\
\text { or equal to about } 2 \% \text {, and the at least one liner } \\
\text { is also configured to damp bending mode } \\
\text { vibrations in the shaft member, the at least one } \\
\text { liner being tuned to within about } \pm 20 \% \text { of a } \\
\text { bending mode natural frequency of the shaft } \\
\text { assembly as installed in the driveline system. }\end{array}$ & $\begin{array}{l}\text { A method for manufacturing a shaft } \\
\text { assembly of a driveline system, the } \\
\text { driveline system further including a first } \\
\text { driveline component and a second } \\
\text { driveline component, the shaft assembly } \\
\text { being adapted to transmit torque between } \\
\text { the first driveline component and the } \\
\text { second driveline component, the method } \\
\text { comprising: providing a hollow shaft } \\
\text { member; tuning a mass and a stiffness of at } \\
\text { least one liner; and inserting the at least } \\
\text { one liner into the shaft member; wherein } \\
\text { the at least one liner is a tuned resistive } \\
\text { absorber for attenuating shell mode } \\
\text { vibrations and wherein the at least one } \\
\text { liner is a tuned reactive absorber for } \\
\text { attenuating bending mode vibrations. }{ }^{248}\end{array}$ \\
\hline
\end{tabular}

240. Id. at 1359, 1355 (Newman, J., dissenting; Chen, J., concurring).

241. Id. at 1348 (Dyk, J., concurring).

242. Id. at 1367 (O'Malley, J., dissenting).

243. Id. at 1354-55 (Chen, J., concurring).

244. Id. at 1351 (Dyk, J., concurring).

245. Id. at 1359 (Newman, J., dissenting) (quoting Hooke's Law, ENCYCLOPÆDiA BRITANNICA, https://www.britannica.com/science/Hookes-law (last visited Dec. 1, 2021) [https://perma.cc/85GU-J3DE]).

246. Id.

247. Id. (quoting U.S. Patent No. 7,774,911 col. 10 11. 10-27 (filed Feb. 27, 2006)).

248. Id. at 1360 (emphasis added) (quoting '911 Patent col. 11 11. 24-36). 


\section{B. Procedural History}

Neapco Holdings LLC and Neapco Drivelines LLC (collectively, "Neapco") contested the validity of AAM's '911 patent. ${ }^{249}$ The district court first found claim 22 to be ineligible for patent protection for claiming nothing more than Hooke's Law. ${ }^{250}$ After a first Federal Circuit panel decision, AAM sought panel rehearing and en banc review. ${ }^{251}$ After granting panel rehearing, the rehearing panel majority ("the panel" or "the majority") found claim 22 to be ineligible on the same grounds in a revised decision. ${ }^{252}$ The Federal Circuit denied en banc rehearing, ${ }^{253}$ and below are the opinions regarding the denial.

\section{The Per Curiam Opinion of the Court}

The per curiam opinion briefly articulated that the poll among the judges for en banc rehearing failed, and thus the court ordered that the petition for rehearing en banc be denied and the mandate of the court be issued on September 8, $2020 .{ }^{254}$

\section{Judge Dyk's Concurrence}

Judge Dyk, joined by Judges Wallach and Taranto, "concur[ed] in the denial of the petition for rehearing en banc." ${ }^{255} \mathrm{He}$ asserted that the panel's opinion was "consistent with precedent and narrow in its scope," and that claim 22 "invokes the natural law [connecting] stiffness, mass, and vibration frequency."256 Invalidating claim 22 and its related claims is consistent with a long line of cases, starting around the time of O'Reilly in 1853, where the Supreme Court invalidated Morse's claim 8 to " "printing intelligible characters . . . at any distances' by the use of 'electro-magnetism." ${ }^{257}$ Thus, because claim 22 does not recite specific details of how the result is achieved, only the natural law, the claim is correctly invalidated under $O^{\prime}$ Reilly and subsequent cases. ${ }^{258}$

Claims which rely on scientific principles can remain patent eligible, contrary to the dissents of Judges Newman and Stoll. ${ }^{259}$ But it is claims such as claim 22 here and claim 8 in $O^{\prime}$ Reilly, which assert only a result and disclose only a natural

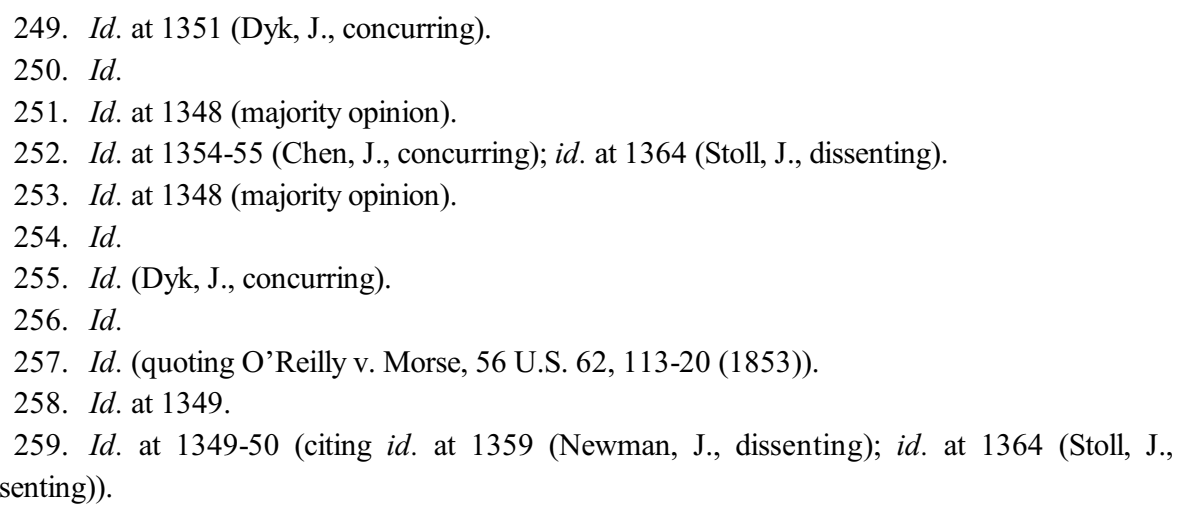


law to achieve that result, that are ineligible. ${ }^{260}$ Claims reciting specific means to achieve the result continue to be patent eligible. ${ }^{261}$

Judge Dyk also disagreed with Judge Stoll, writing that there is no factual issue here. ${ }^{262}$ If Judge Stoll was asking whether more than Hooke's Law is required to make a device capable of producing the claimed result, then this is not a proper eligibility question. ${ }^{263}$ O'Reilly invalidated Morse's claim 8 for using electromagnetism to produce the claimed result, even though it was plain from the specification and other claims that more than electromagnetism was needed. ${ }^{264}$ The claim required more detail to be eligible. ${ }^{265}$

Step one of the "directed to" inquiry, which asks what the claim says, may include factual issues. ${ }^{266}$ But here, both parties' witnesses agreed that the claims invoke the relationship between frequency, mass, and stiffness, as Hooke's Law recites. ${ }^{267}$ Though "claim 22 does not name Hooke's law," this is "immaterial."268 The claim need not name the law of nature to be rejected under a $\S 101$ analysis. ${ }^{269}$

Judge Dyk wrote that Judge O'Malley is incorrect in suggesting that the panel majority decided the case on unargued grounds and announced a new test for patent eligible subject matter. ${ }^{270}$ Neapco argued in the district court and on appeal that the claims invoked a natural law, and nothing more, to achieve the desired result, arguments to which AAM responded. ${ }^{271}$

Holding that claim 22 is "nothing more" than a natural law did not articulate a new patent eligibility test, in Judge Dyk's view. ${ }^{272}$ Questioning if a claim recites "nothing more" is a linguistic formulation the Federal Circuit has previously applied to $\S 101$ inquiries. ${ }^{273}$ The parties and district court also used this linguistic formulation. ${ }^{274}$ Thus, en banc rehearing is not necessary. ${ }^{275}$

260. Id.

261. Id.

262. Id. at 1350 (citing id. at 1363-65 (Stoll, J., dissenting)).

263. Id.

264. Id.

265. Id.

266. Id.

267. Id. at 1351 .

268. Id.

269. Id. (citing Mayo Collaborative Servs. v. Prometheus Labs., Inc., 566 U.S. 66, 72, 77 (2012)).

270. Id. (citing id. at 1365-66 (O'Malley, J., dissenting)).

271. Id.

272. Id.

273. Id. at 1352 .

274. Id.

275. Id. at 1348 . 


\section{E. Judge Chen's Concurrence}

Judge Chen, joined by Judge Wallach, also wrote to concur with the court's outcome. ${ }^{276}$ Judge Chen notes the panel did not create any new patent eligibility tests. ${ }^{277}$ The test dubbed by the dissent as the new "nothing more" test has been a principle of patent law since at least $1853 .{ }^{278}$ The principle recites that a claim may be ineligible for patent protection if it invokes a natural law to achieve a desired result and recites "nothing more."279 In O'Reilly, the Supreme Court articulated this principle and invalidated Morse's claim 8 to using electromagnetism and nothing more to generate and send messages at a distance ${ }^{280}$ Claim 22 of the ' 911 patent, once construed, is substantively the same as Morse's claim 8 in that it calls for the use of Hooke's Law to dampen vibrations. ${ }^{281}$

Nor did the panel's opinion create a new patent eligibility test which excludes from patent eligibility any claims that implicitly require the application of an unstated natural law. ${ }^{282}$ The $O$ 'Reilly test applies when a claim recites a limitation which, when construed, expressly invokes a particular law of nature. ${ }^{283}$ Here, claim 22, as construed, expressly invokes Hooke's Law by instructing to tune mass and stiffness to adjust frequency. ${ }^{284}$

The difference in outcomes between claims 1 and 22 illustrated the lack of new legal test. ${ }^{285}$ Claim 1 omits any limitation of "tuning to match the relevant frequency" to mass and stiffness. ${ }^{286}$ There is thus no basis to say that claim 1 expressly invokes Hooke's Law or runs afoul of $O$ 'Reilly by expressly invoking a natural law. ${ }^{287}$ But the panel upheld claim 1 even though it may implicitly rely on Hooke's Law, thus showing that there is no new patent eligibility test for claims which implicitly rely on a natural law. ${ }^{288}$

The court need not remand, as the dissent suggests, to have the district court apply the $O^{\prime}$ Reilly test in the first instance. ${ }^{289}$ The district court already applied O'Reilly's principles in the same way that the panel majority did when it held

276. Id. at 1352 (Chen, J., concurring).

277. Id.

278. Id.

279. Id. at 1353 .

280. Id. at 1352-53 (citing O’Reilly v. Morse, 56 U.S. 62, 112-13 (1853)).

281. Id. at 1353 .

282. Id. at 1355.

283. Id.

284. Id.

285. Id.

286. Id.

287. Id. The specification confirms that there are other ways to tune to adjust the frequency than by adjusting mass and stiffness.

288. Id. at 1355-56.

289. Id. at 1354 . 
claim 22 to be invalid for merely invoking Hooke's Law to achieve a result. ${ }^{290}$

Although some question the district court and panel's decisions, Judge Chen noted that $\S 101$ analyses are context-driven. ${ }^{291}$ But given the context of the claim language of tuning the liner's mass and stiffness, the undisputed claim construction of using the mass and stiffness to tune the frequencies, the mathematical relationship in Hooke's Law between mass, stiffness, and frequency, and the district court's rejection of AAM's argument that claim 22 does not refer to Hooke's Law, it seemed reasonable to Judge Chen that claim 22 be found ineligible. ${ }^{292}$

Some amici suggested that the panel misunderstood O'Reilly. ${ }^{293}$ These amici suggested that Mr. Morse's upheld claims begin with a natural law and end with the desired result without reciting any other claim limitations. ${ }^{294}$ But Morse's patent-eligible claims incorporated the limitations set forth in the specification. ${ }^{295}$ Morse's claim 8, in contrast, disavowed any implementation details from the specification. ${ }^{296}$ In addition to the difference in claim language, the Supreme Court reiterated the principles of O'Reilly in Dolbear v. American Bell Telephone Co., that claims which recite a law of nature to achieve a result, and nothing more, are not patent eligible, but claims which incorporate implementation details from the specification are patent-eligible. ${ }^{297}$

290. Id. (collecting applications).

291. Id. at 1355.

292. Id.

293. Id. at 1353 (citing Brief of 12 Law Professors as Amici Curiae in Support of PetitionerAppellant at 6-8, Am. Axle, 966 F.3d 1347 (No. 113-1), 2019 WL 6839240, at *6-8).

294. Id.

295. Id. (citing U.S. Reissue Patent No. 117 (issued June 13, 1848)). For example, claim 1 reads:

Making use of the motive power of magnetism when developed by the action of such current or currents, substantially as set forth in the foregoing description of the first principal part of my invention, as means of operating or giving motion to machinery which may be used to imprint signals upon paper or other suitable material, or to produce sounds in any desired manner for the purpose of telegraphic communication at any distances.

Id. (emphasis in original).

296. Id. (citing U.S. Reissue Patent No. 117 (issued June 13, 1848)). Claim 8 reads:

I do not propose to limit myself to the specific machinery or parts of machinery described in the foregoing specifications and claims, the essence of my invention being the use of the motive power of the electric or galvanic current, which I call "electromagnetism," however developed, for marking or printing intelligible characters, signs, or letters at any distances, being a new application of that power of which I claim to be the first inventor or discoverer.

Id. (emphasis in original).

297. Id. at 1353-54 (citing Dolbear v. Am. Bell Tel. Co., 126 U.S. 1, 531-32 (1888)) (Dolbear held eligible a claim to "transmitting vocal or other sounds telegraphically, as herein described." (emphasis added)). 
Judge Chen disagreed with AAM and amici contentions that mechanical and industrial inventions are categorically excluded from $\S 101$ concerns. ${ }^{298}$ The Supreme Court first discussed patent eligibility concerns on industrial-revolution era inventions. ${ }^{299}$

Finally, Judge Chen disagreed with the dissent's position that the panel majority's decision created a heightened enablement standard. ${ }^{300}$ The majority correctly explained that $\S 101$ constrains the claims, whereas enablement imposes a different requirement on the specification to those claims. ${ }^{301}$ The panel went no further than $O^{\prime}$ Reilly, a case about $\S 101$, required. ${ }^{302}$

\section{F. Judge Newman's Dissent}

Judge Newman wrote to dissent from the denial of en banc rehearing in this case. ${ }^{303}$ Joined by Judges Moore, O'Malley, Reyna, and Stoll, she wrote to express that the growing uncertainty surrounding patent eligibility shows the need for en banc rehearing. ${ }^{304}$

Judge Newman rejected Neapco and the panel majority's conclusion that the breadth of the claim is "critically material to the $\S 101$ inquiry" in addition to the novelty, obviousness, written description and enablement inquiries. ${ }^{305}$ She wrote that the district court should have considered whether the application of the scientific principle is new, non-obvious, or enabled, in addition to considering whether claim 22 is drawn to a scientific principle and nothing more. ${ }^{306}$ Further, the court did not assess "whether there are substantive issues of claim scope related to invalidity or infringement." ${ }^{\text {"307 }}$ These missteps are made conspicuous by the panel majority's treatment of Hooke's Law as the basis of finding the claim ineligible. ${ }^{308}$ At no point is the Court told what Hooke's Law is, or how precisely it invalidates AAM's automotive driveshaft. ${ }^{309}$

Judge Newman failed to find a difference in why claim 1, the broadest claim, is patent-eligible, while claim 22 is not. ${ }^{310}$ Responding to Judge Dyk's discussion of Morse's claim 8 in $O$ 'Reilly, claim 8 was not ineligible because the claim did not incorporate the limitations in the specification; claim 8 was ineligible because

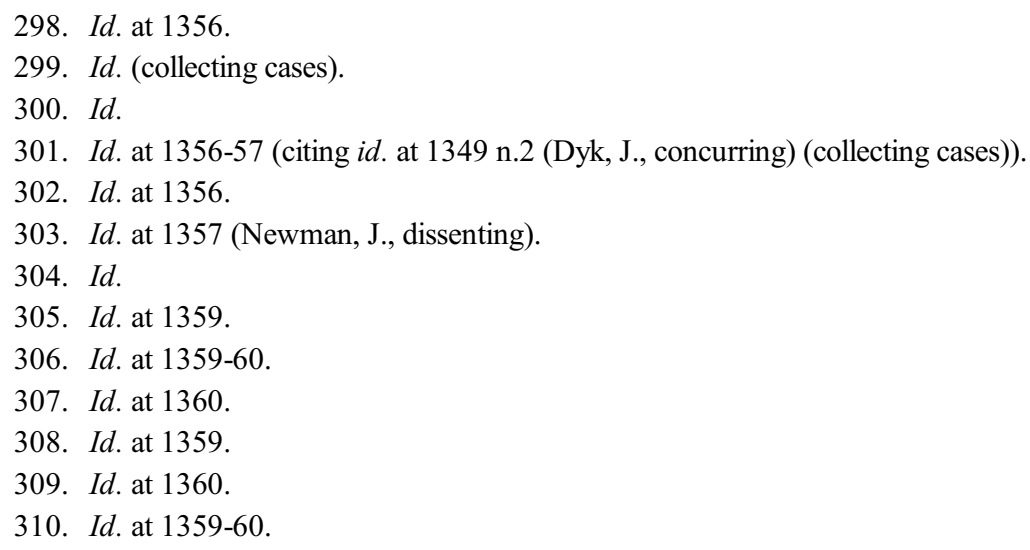


it sought to claim electromagnetism as a scientific principle. ${ }^{311}$ In contrast, it is apparent that AAM's claims are drawn to an automotive driveshaft, not to an abstract idea or law of nature. ${ }^{312}$

This case contained many policy implications. Judge Newman noted that all technology is based on scientific principles, "whether or not the principles are understood." 113 "At some level, 'all inventions . . embody, use, reflect, rest upon, or apply laws of nature, natural phenomena, or abstract ideas." 314 These building blocks of inventions cannot be patented, but useful applications of such concepts remain eligible for patent protection. ${ }^{315}$ Such an understanding is fundamental to achieve the constitutional goal of promoting scientific progress and the useful arts. ${ }^{316}$

The Federal Circuit, until recently, appropriately implemented the law. ${ }^{317}$ But this case departed from precedent, and added to the concerns of amici curiae that the panel decision in this case reflects a trend of courts narrowing the types of inventions eligible for patent protection under the two-step Mayo-Alice inquiry. ${ }^{318}$ Retired Judge Paul R. Michel noted that the uncertainty promulgated by these $\S$ 101 rulings "threaten[s] to undercut patent law and its innovation-promoting goals." ${ }^{\prime 19}$ The Alliance of U.S. Startups and Inventors for Jobs noted that patents no longer provide adequate comfort for investors of innovative technologies, nor do patents provide security to inventors who seek to create breakthrough technologies. ${ }^{320}$ Reliability must be restored to the patent system, as innovation is a foundation of the "nation's economy, trade, and strength." 321 En banc review is warranted to address these concerns. ${ }^{322}$

\section{G. Judge Stoll's Dissent}

Judge Stoll, joined by judges Newman, Moore, O’Malley, and Reyna, also

311. Id. at 1360 .

312. Id.

313. Id. at 1357.

314. Id. at 1358 (quoting Alice Corp. v. CLS Bank Int'l, 573 U.S. 208, 217 (2014) (internal citations and alterations omitted)).

315. Id. (citing Le Roy v. Tatham, 55 U.S. 156, 174-75 (1853)).

316. Id.

317. Id. (discussing Enfish, LLC v. Microsoft Corp., 822 F.3d 1327, 1335 (Fed. Cir. 2016); In re TLI Commc'ns LLC Patent Litig., 823 F.3d 607, 611 (Fed. Cir. 2016)).

318. Id. at 1360 (citing Brief of Amicus Curiae Biotechnology Innovation Org. in Support of Appellant's Combined Pet. for Rehearing or Rehearing En Banc at 1, Am. Axle, 966 F.3d 1347 (No. 18-1763); Brief of 12 Law Professors, supra note 293, at 2).

319. Id. at 1360-61 (quoting Brief of Amicus Curiae Paul R. Michel, U.S. Circuit Judge (Ret.) in Support of Rehearing En Banc, Am. Axle, 966 F.3d 1347 (No. 2018-1763)).

320. Id. at 1361.

321. Id.

322. Id. 
wrote to dissent from the denial of en banc rehearing. ${ }^{323}$ Judge Stoll first took issue with the panel's application of O'Reilly's principles and the new "nothing more" test to this case. ${ }^{324}$ Morse's claim 8 is facially distinguishable from claim 22 , as Morse's claim 8 was not limited to any particular implementation and instead attempted to claim the use of electromagnetism, however developed, to transmit information. ${ }^{325}$ Here, however, claim 22 attempted to claim the process and machinery necessary to produce the desired effect of reducing vibrations. ${ }^{326}$

The majority also misunderstood why the other claims in O'Reilly were upheld. ${ }^{327}$ O'Reilly did not expressly hold the other claims eligible because they incorporated information by reference to the specification. ${ }^{328}$ Based on this and the differences in the claim language of implementation process and machinery, the majority's "nothing more" test expanded the sway of precedent, and thus en banc review is necessary. ${ }^{329}$

To Judge Stoll, the fact that the "nothing more" linguistic formulation has been used before does not mean this test is not new, contrary to Judge Dyk's position. ${ }^{330}$ This is highlighted by the fact that the concurrences provide no details on what the "nothing more" test entails. ${ }^{331}$ Because this test has not been developed and is appearing in recent $\S 101$ jurisprudence, the court should have granted en banc review to develop this test. ${ }^{332}$

Judge Stoll agreed with Judge Moore's dissent that the application of the new "nothing more" test to this case requires factual inquiries be resolved by the district court. ${ }^{333}$ Particularly, the expert opinions conflicted on whether this claim can be reduced to Hooke's Law and nothing more. ${ }^{334}$ This is not purely a legal question because the intrinsic evidence does not mention Hooke's Law; extrinsic evidence is required. ${ }^{335}$

In responding to Judge Chen's assertion that this is a straightforward application of the O'Reilly test "consistent with long-standing precedent," Judge Stoll wrote that prior to this case, there was no O'Reilly test. ${ }^{336}$ Further, O'Reilly's role as precedent in recent years has been only for the principle that there is an implicit exception to $\S 101$ regarding preemption. ${ }^{337}$

323. Id. (Stoll, J., dissenting).

324. Id. at 1361-62.

325. Id. at 1361 (citing O'Reilly v. Morse, 56 U.S. 62, 112 (1853)).

326. Id. at 1362 (citing $O^{\prime}$ Reilly, 56 U.S. at 120).

327. Id.

328. Id. (quoting Dolbear v. Am. Bell Tel. Co., 126 U.S. 1, 534 (1888)).

329. Id.

330. Id. (citing id. at $1352 \mathrm{nn} .4-7$ (Dyk, J., concurring)).

331. Id. at 1363.

332. Id.

333. Id. at 1364 .

334. Id.

335. Id.

336. Id. at 1362 (citing $i d$. at 1352, 1353-55 (Chen, J., concurring)).

337. Id. (collecting Supreme Court cases). 
The panel majority's decision also blurred the line between patent eligibility and enablement under $\S 101 .{ }^{338}$ Eligibility considers whether the claim had "the specificity required to transform a claim from one claiming only a result to one claiming a way of achieving it. ${ }^{" 339}$ Claims directed to an application of a natural law can be specific enough to be eligible even though they do not include all of the "how to" claim steps that enablement requires in the specification. ${ }^{340}$ By requiring the claims include specific "how to" implementation steps, the majority seemed to incorporate an enablement standard into $\S 101 .^{341}$ The "911 patent included many specific details as to how to adjust the frequencies, sufficient to transform the claim into an eligible application of the law of nature. ${ }^{342}$ The majority's lack of discussion of the how-to details in the patent highlighted the need for en banc rehearing. ${ }^{343}$

Judge Stoll believed that the Court has strayed too far from preemption concerns to find this method of manufacturing claim ineligible. ${ }^{344}$ "The claims at issue here are far removed from the canonical ineligible claim that 'simply state[s] the law of nature while adding the words "apply it.",",345

To conclude, Judge Stoll noted that this decision will likely invite more eligibility challenges to mechanical patents. ${ }^{346}$ En banc review is needed to prevent these judicial exceptions from "swallow[ing] all of patent law." ${ }^{\text {"34 }}$

\section{H. Judge O'Malley's Dissent}

Judge O'Malley wrote in dissent, and was joined by Judges Newman, Moore, and Stoll. ${ }^{348}$ Judge O'Malley raised a procedural concern: the panel found claim ineligibility based on unargued and unbriefed grounds, in violation of a request from the Advisory Committee on Appellate Rules. ${ }^{349}$ The American Academy of Appellate Lawyers wrote to the Advisory Committee, requesting that appellate courts give notice to the parties and an opportunity to brief the issue when an appellate court is considering ruling on a previously unaddressed ground. ${ }^{350}$

338. Id. at 1363 .

339. Id. (emphasis added) (quoting SAP Am., Inc. v. InvestPic, LLC, 898 F.3d 1161, 1167-68

(Fed. Cir. 2018)) (collecting cases).

340. Id.

341. $I d$.

342. Id.

343. Id.

344. Id.

345. Id. (quoting Mayo Collaborative Servs. v. Prometheus Labs., Inc., 566 U.S. 66, 72 (2012)).

346. Id. at 1364-65.

347. Id. at 1365 (quoting Alice Corp. v. CLS Bank Int'l, 573 U.S. 208, 217 (2014)).

348. Id. (O'Malley, J., dissenting).

349. $I d$.

350. See id. (quoting Letter from the Am. Acad. of Appellate Lawyers to Michael Chagares, Chair, Fed. Advisory Comm. on Appellate Rules (Apr. 26, 2019), https://www.appellateacademy. 
Rather than implement a formal mandate, the Advisory Committee requested appellate courts to implement this request directly. ${ }^{351}$

Judge O'Malley asserted that the panel decided parts of this case on unargued and unbriefed grounds. ${ }^{352}$ The district court did not discuss $O$ 'Reilly, nor did it find that there was "nothing more" than a natural law in claim 22. ${ }^{353}$ On appeal, the panel sua sponte construed claims 1 and 22 to be patentably different with respect to "inserting versus positioning" the liner. ${ }^{354}$ The parties never argued these terms. ${ }^{355}$ The majority used the minor difference in wording as a hook to set up the $\S 101$ abstract idea discussion. ${ }^{356}$ Finally, the panel majority remanded to the district court to effectuate the abstract idea discussion, which had not been raised previously. ${ }^{357}$

Judge O'Malley agreed with the other dissents that the majority articulated a new test, that a patent is ineligible when it "clearly invokes a natural law, and nothing more, to accomplish a desired result." 358 Judge O'Malley believed this expansion of O'Reilly would even render the upheld claims of O'Reilly ineligible. ${ }^{359}$ The court also should have remanded to the district court to apply the test in the first instance. ${ }^{360}$

\section{Status of American Axle \& Manufacturing v. Neapco Holdings LLC as of the Drafting of this Article}

AAM filed a petition for writ of certiorari at the Supreme Court on December $28,2020 .{ }^{361}$ As of the final date of drafting of this article (April 1, 2021), the Supreme Court has not yet decided AAM's petition, but respondent Neapco had submitted its response in opposition to AAM's petition and several amici curiae have also filed briefs. ${ }^{362}$

org/publications/Chagares_proposal.pdf[https://perma.cc/D2PD-HVEF]).

351. Id.

352. See id. at 1366-67.

353. Id. at 1366 (citing Am. Axle \& Mfg., Inc. v. Neapco Holdings LLC, 309 F. Supp. 3d 218, 225 (D. Del. 2018)).

354. Id.

355. Id. at 1366-67.

356. Id. at 1367.

357. Id.

358. Id. at 1366.

359. See id.

360. Id.

361. See No. 20-891: American Axle \& Manufacturing Inc., Petitioner v. Neapco Holdings LLC, et al., SuP. Cт. U.S., https:/www.supremecourt.gov/docket/docketfiles/html/public/20891.html (last visited Dec. 8, 2021) [https://perma.cc/8MPC-RUQS].

362. Id. 


\section{COPYRIGHT PROTECTION FOR MUSICAL WORKS: SKIDMORE V. LED ZEPPELIN}

In Skidmore v. Led Zeppelin, the Ninth Circuit issued an en banc decision in a copyright case involving the iconic rock n' roll song "Stairway to Heaven." 363 While upholding a jury finding that "Stairway to Heaven" did not infringe an earlier songwriter's copyright, the Ninth Circuit held, among other things, that it was appropriate for the lower court to limit a substantial similarity analysis to the similarities between the contents of a deposit copy of a copyrighted song and the alleged infringing song. ${ }^{364}$ The court also explicitly rejected the "inverse ratio rule," in which courts in the circuit had previously "permitted a lower standard of proof of substantial similarity" between the copyrighted song and allegedly infringing song "where there is a high degree of access." 365

The widely publicized case involved allegations by the estate of guitarist Randy Wolfe (known in the music industry as "Randy California") that the band Led Zeppelin's iconic rock and roll ballad "Stairway to Heaven" infringed a copyright in Wolfe's song "Taurus." 366 The Ninth Circuit's en banc decision received significant attention by industry associations and legal scholars and continues to resonate in disputes between songwriters in other courts. ${ }^{367}$

\section{A. Background}

Wolfe wrote "Taurus" for his band Spirit in the 1960s. ${ }^{368}$ In 1967, his record company, Hollenbeck Music Co. ("Hollenbeck"), registered a copyright for "Taurus," listing Wolfe as the author. ${ }^{369}$ As part of the registration, Hollenbeck transcribed the song and deposited one page of sheet music with the U.S. Copyright Office. ${ }^{370}$ Several years later in 1971, Led Zeppelin released an album that included the song "Stairway to Heaven." ${ }^{371}$ There was no dispute that members of the bands knew of each other and had heard each other's music; however, there was no evidence that members of Led Zeppelin had specifically heard Spirit perform "Taurus."

Forty-three years after the release of "Stairway to Heaven," a co-trustee of

363. Skidmore v. Led Zeppelin, 952 F.3d 1051 (9th Cir. 2020) (en banc).

364. Id. at 1079 .

365. Id.

366. Id. at 1056 .

367. The case attracted significant attention from copyright scholars and drew the submission of amicus briefs from numerous parties including from the Department of Justice, United States Copyright Office, National Music Publishers' Association, Recording Industry Association of America, National Music Publishers Association, and numerous intellectual property professors. See id. at 1055.

368. Id. at 1056.

369. Id. at 1056-57.

370. Id. at 1057.

371. Id.

372. Id. 
Wolfe's estate, Michael Skidmore, filed suit against Led Zeppelin in the Central District of California for copyright infringement and a claim he titled "Right of Attribution-Equitable Relief-Falsification of Rock n' Roll History." 373 Skidmore's allegations of copyright infringement were "that the opening notes of Stairway to Heaven are substantially similar to the eight-measure passage at the beginning of the Taurus deposit copy." ${ }^{374}$ The Ninth Circuit described his allegations regarding the opening notes as follows:

The claimed portion includes five descending notes of a chromatic musical scale. These notes are represented on the piano as a set of adjacent black and white keys, from right to left. The beginning of Stairway to Heaven also incorporates a descending chromatic minor chord progression in A minor. However, the composition of Stairway to Heaven has a different ascending line that is played concurrently with the descending chromatic line, and a distinct sequence of pitches in the arpeggios, which are not present in Taurus. ${ }^{375}$

The case eventually went to trial on Skidmore's copyright infringement claim (the rock n' roll history claim, while creative, had been disposed of on summary judgment). ${ }^{376}$ The jury reached a verdict that Led Zeppelin did not infringe Wolfe's copyright, and the two songs were not substantially similar. ${ }^{377}$ Skidmore appealed and the defendants cross-appealed the lower court's denial of their motions for attorneys' fees and costs. ${ }^{378}$ The appeals were consolidated, and a Ninth Circuit panel vacated the judgment in part and remanded for a new trial. The circuit court then granted rehearing en banc. ${ }^{379}$

\section{B. The Ninth Circuit's En Banc Decision}

The Ninth Circuit's en banc decision addressed a number of legal issues, the most noteworthy of which were rulings on the importance of the contents of the Taurus deposit copy and its abolishment of the inverse ratio doctrine.

1. The Deposit Copy Requirement Under the Copyright Act of 1909.Skidmore argued on appeal that the district court had erred by refusing to allow evidence at trial of "Taurus" recordings that included embellishments and song elements that were not included in the deposit copy that Hollenbeck submitted when applying for the copyright. ${ }^{380}$ The Ninth Circuit disagreed, holding that the district court had correctly ruled that under the Copyright Act of 1909 (the "1909 Act"), which controlled this case, the scope of Skidmore's copyright protection

\footnotetext{
373. Id.

374. Id.

375. Id. at 1058 .

376. Id.

377. Id. at 1060 .

378. Id.

379. Id.

380. Id. at 1063-64.
} 
as an unpublished work was defined by the deposit copy. ${ }^{381}$

The "Taurus" copyright was registered in 1967, prior to enactment of the comprehensive Copyright Act of $1976 .{ }^{382}$ The Ninth Circuit determined that due to this fact, the copyright was subject to the requirements of the 1909 Act. ${ }^{383}$ The court referred to the text of the 1909 Act, which stated that for unpublished works, "copyright may also be had of the works of an author of which copies are not reproduced for sale, by the deposit, with claim of copyright, of one complete copy of such work if it be a . . musical composition . . . ${ }^{3384}$ Focusing on the complete copy language, the court concluded that under the 1909 Act, the scope of the "Taurus" copyright protection, as an unpublished work, was limited to the deposit copy that Hollenbeck originally submitted for the copyright application-specifically, the one page of sheet music that had been described and deposited. ${ }^{385}$

Skidmore argued to the contrary that the scope of the "Taurus" copyright protection "extends beyond the sheet music; that is, the deposit copy is somehow archival in nature and more of a reference point than a definitive filing." ${ }^{386}$ Skidmore also cited cases for the proposition that the deposit copy can be supplemented, supporting the proposition that copyright protection is not limited by the bounds of what is in the deposit copy. ${ }^{387}$ But the court distinguished and found the cited cases to be inapposite and concluded that his arguments were insufficient to overcome the statutory requirement of a complete deposit copy. ${ }^{388}$

The court thus concluded that copyright protection for unpublished works under the 1909 Act is limited to what is included in the deposit copy and that the district court had properly excluded evidence of performances of "Taurus" that included musical elements which were not present in the deposit copy for the substantial similarity analysis. ${ }^{389}$

2. Ending the Inverse Ratio Doctrine.- The court also addressed the "inverse ratio rule," which courts have applied as part of the copyright infringement analysis and requires "a lower standard of proof of substantial similarity when a high degree of access is shown." ${ }^{\text {"390 }}$ Skidmore had requested that the district court give a jury instruction on the inverse ratio doctrine, but the district court had refused. ${ }^{391}$ On appeal, the Ninth Circuit strongly condemned the doctrine: describing a "constellation of problems and inconsistencies in [its] application";

381. Id.

382. Id. at $1060-61$.

383. Id. at 1061 .

384. Id. at 1062 (quoting Copyright Act of 1909, Pub. L. No. 60-349, § 11).

385. Id. at 1064.

386. Id. at 1062.

387. Id. at 1063 .

388. Id.

389. Id. at 1079.

390. Id. at 1066 (quoting Three Boys Music Corp. v. Bolton, 212 F.3d 477, 485 (9th Cir. 2000))

391. Id. 
pointing out that, among other issues, it alters the burden of proof from a preponderance of the evidence to an inverse burden, as well as unfairly favoring copyright protection for famous works where significant levels of access exist; and concluding that no degree of access to a copyrighted work "obviate[s] the requirement that the plaintiff must demonstrate that the defendant actually copied the work." ${ }^{392}$

After taking on a number of additional issues, ranging from other jury instructions to attorneys' fees, the en banc court concluded its lengthy opinion by affirming the district court's judgment that Led Zeppelin's "Stairway to Heaven" did not infringe the "Taurus" copyright. ${ }^{393}$ The Supreme Court denied certiorari in September 2020. ${ }^{394}$

\section{STATE COURT JURISDICTION OVER PATENT-RELATED MATTERS: WARSAW ORTHOPEDIC, INC. V. SASSO}

On December 4, 2020, the Indiana Court of Appeals affirmed a jury verdict of nearly $\$ 112.5$ million in favor of plaintiff-appellee Dr. Rick C. Sasso for breach of two contracts related to two of Dr. Sasso's spinal surgery patents. ${ }^{395} \mathrm{In}$ doing so, the court addressed and rejected defendant-appellants Medtronic, Inc., Medtronic Sofamor Danek, Inc., and Warsaw Orthopedic, Inc.'s (collectively, "Medtronic") argument that the dispute arises under patent law, which is within the exclusive jurisdiction of federal courts, ${ }^{396}$ among other issues. ${ }^{397}$

\section{A. Factual Background}

Dr. Sasso is a renowned spinal surgeon based in Indiana and graduated medical school in $1986 .{ }^{398}$ Since then, Dr. Sasso has devised innovative surgical techniques and devices. ${ }^{399}$ Medtronic sells spinal surgery products and often collaborates with spinal surgeons to bring new products to market. ${ }^{400}$ At issue in this case are two agreements resulting from the collaboration between Dr. Sasso and Medtronic: the Screw Agreement and the Vertex Agreement. ${ }^{401}$

The Screw Agreement relates to a technique devised by Dr. Sasso for minimizing incisions during spinal surgery by using a tube to guide surgical implements and instructions. ${ }^{402}$ Discussions about the Screw Agreement began in the mid-1990s and ultimately culminated in Medtronic agreeing to pay Dr.

392. Id. at 1069.

393. Id. at 1079.

394. Skidmore v. Led Zeppelin, 141 S. Ct. 453, 454 (2020).

395. Warsaw Orthopedic, Inc. v. Sasso, 162 N.E.3d 1, 5 (Ind. Ct. App. 2020).

396. 28 U.S.C. $§ 1338$ (a) (2019).

397. Sasso, 162 N.E.3d at 12.

398. $I d$. at $5-6$.

399. Id. at 6 .

400. Id.

401. Id.

402. Id. 
Sasso royalties for rights to the Invention ${ }^{403}$ and Intellectual Property Rights, ${ }^{404}$ although the royalties were not contingent on Medical Devices (defined as products including the Invention listed in Schedule B of the Screw Agreement) being covered by a valid patent. The duration of the Screw Agreement was governed by the following language:

Unless sooner terminated, this Agreement shall expire upon the last to expire of the patents included in Intellectual Property Rights, or if no patent application(s) issue into a patent having valid claim coverage of the Medical Device, then seven (7) years from the Date of First Sale of the Medical Device. ${ }^{405}$

Dr. Sasso ultimately received a patent on his invention, U.S. Patent No 6,287,313, entitled "Screw Delivery System and Method." 406 The application was filed in November 1999 and issued in September 2001..$^{407}$

The Vertex Agreement covered Dr. Sasso's work with Medtronic to develop a posterior spinal rod system. ${ }^{408}$ The Vertex Agreement provided that Medtronic would pay Dr. Sasso royalties for the Invention and Intellectual Property Rights relating thereto:

A royalty payment in the amount of two percent (2\%) of the Net Sales of the Medical Device [defined as products including the Invention listed in Schedule B of the Vertex Agreement as a product] for a period of eight (8) years from the date of the first commercial sale of the Medical Device(s). However, if the Medical Device is covered by a valid claim of an issued U.S. patent arising out of the Intellectual Property Rights, then the royalty payment specified above will be payable for the life of the patent. ... ${ }^{409}$

Dr. Sasso, among other co-inventors, was awarded U.S. Patent No. 6,485,491 (the "“491 Patent") for the Vertex system. ${ }^{410}$ Dr. Sasso subsequently contributed to two other patents to improve upon the "491 Patent. ${ }^{411}$

\section{B. Procedural History}

In 2013, Medtronic stopped paying royalties to Dr. Sasso. As a result, Dr.

403. Id. The Screw Agreement defined "Invention" as "any product, method or system relating to a facet screw instrumentation and a headless facet screw fixation system." Id. at 6 n. 4 .

404. Id. at 6 n.5.

405. Id. at 7 (emphasis added).

406. Id.

407. Id.

408. Id. at 8. The technique would give surgeons more flexibility in anchoring and aligning screws and plates in the cervical spine, thereby reducing patient recovery time. Id.

409. Id. at 9 .

410. Id. at $9-10$.

411. Id. at 10 . 
Sasso sued the Medtronic for breach of the Screw and Vertex Agreements. ${ }^{412}$ Three times, Medtronic sought to move the dispute to federal court. First, Medtronic removed the case to the Northern District of Indiana, alleging exclusive federal jurisdiction under patent laws. ${ }^{413}$ The district court, however, determined that the case turned on Indiana contract law, not federal patent law. Second, Medtronic filed a motion to dismiss with the trial court, arguing that Dr. Sasso's breach-of-contract claims depended upon patent law and, thus, were exclusively in the jurisdiction of the federal courts. ${ }^{414}$ The trial court likewise disagreed. Third, Medtronic filed a declaratory judgment complaint in the Northern District of Indiana, seeking a declaration that it owed nothing under the agreements. ${ }^{415}$ The district court declined to exercise jurisdiction over the claim under the doctrine of abstention (the doctrine that a district court may refuse to hear a case if it may intrude on the powers of another court), which the Federal Circuit affirmed. ${ }^{416}$

Meanwhile, Medtronic also challenged the validity of Dr. Sasso's patents. In 2018, Medtronic challenged the validity of the ' 313 Patent by filing a request for ex parte reexamination with the USPTO.${ }^{417}$ However, Dr. Sasso filed a motion for partial summary judgment with the trial court, arguing that the terms of the agreements did not depend on the validity of his patents. ${ }^{418}$ The trial court granted the motion. ${ }^{419}$

After the fifteen-day jury trial, the USPTO determined that the challenged claims of the ' 313 Patent were invalid. ${ }^{420}$

On appeal, Medtronic again argued that the trial court lacked subject matter jurisdiction over the patent-related dispute. ${ }^{421}$

\section{Subject Matter Jurisdiction Analysis}

Claims arise under the law which creates the cause of action. ${ }^{422}$ According to the Indiana Court of Appeals, because the breach of contract claim arises under state law, the state court maintains jurisdiction over the claim even though there are patent-related issues. ${ }^{423}$ Thus, the court affirmed.

In general, claims that "arise under" patent law (e.g., patent infringement) are within the exclusive jurisdiction of federal courts:

\footnotetext{
412. Id.

413. $I d$.

414. Id.

415. Id. at 11 .

416. Id.

417. Id.

418. Id.

419. Id.

420. Id.

421. Id. at 12 .

422. Id.

423. Id.
} 
(a) The district courts shall have original jurisdiction of any civil action arising under any Act of Congress relating to patents, plant variety protection, copyrights and trademarks. No State court shall have jurisdiction over any claim for relief arising under any Act of Congress relating to patents, plant variety protection, or copyrights. . . . ${ }^{424}$

The reason is simple: to promote national uniformity in the realm of intellectual property ${ }^{425}$ State courts maintain jurisdiction over patent-related claims, however, that "arise under" state law (e.g., breach of contract). ${ }^{426}$ A "special and small category" of cases are the exception, and determining whether a case falls within this "small and special category" requires courts to look to the four-step Gunn standard: "the claim must include a federal issue that is (1) necessarily raised, (2) actually disputed, (3) substantial, and (4) capable of resolution in federal court without disrupting the federal-state balance approved by Congress. ${ }^{, 427}$

Here, the court found that state jurisdiction was proper based on the "substantial" step of the Gunn standard. To reach this decision, the court considered three sub-factors to determine whether a patent-related claim is important "to the federal system as a whole": (a) whether the issue is one of law or of fact; (b) whether a decision on the issue would control other cases; and (c) whether the government has a strong interest in litigating in a federal forum. ${ }^{428}$ As to each factor, the court determined: (a) the issue of breach of contract is one of fact; (b) the outcome would control only the parties to the contract because the patent had already expired; and (c) the government did not have a strong interest in hearing a state contract claim in federal court. ${ }^{429}$ Thus, according to the court, the patent-related claim at issue was not "substantial."

The court also rejected an argument that the related Federal Circuit opinion was barred by the doctrine of res judicata. In the appeal from Medtronic's declaratory judgment action against Dr. Sasso, the Federal Circuit addressed the Gunn factors and determined that they were satisfied even though it affirmed the district court's decision to decline to exercise jurisdiction under the doctrine of abstention. ${ }^{430}$ Medtronic argued that this finding barred the state court from reaching a different conclusion as to the Gunn factors. ${ }^{431}$ The court disagreed,

424. Id. (emphasis in original) (quoting 28 U.S.C. $§ 1338$ (2011)).

425. Id.

426. Id.

427. Id.

428. Id. at 13 (citing MDS (Canada) Inc. v. Rad Source Techs., Inc., 720 F.3d 833, 842 (11th Cir. 2013)).

429. Id. at 14-15; see also id. at 16-17 (discussing Jang v. Bos. Sci. Corp., 767 F.3d 1334, 1337 (Fed. Cir. 2014) (holding that there was exclusive federal jurisdiction because the right to recovery depended on the plaintiff showing infringement of the patent; the issues were substantial because the patent hadn't yet expired, so it could affect other parties; and there was the potential for inconsistent judgments if the state court handled the claim)).

430. Id. at 13 (citing Warsaw Orthopedic v. Sasso, 977 F.3d 1224, 1229 (Fed. Cir. 2020)).

431. Id. 
reasoning that res judicata only applies where there is "relitigation of the same claim or issue in a subsequent lawsuit." ${ }^{\text {"432 }}$ According to the court, because the declaratory judgment action was not "a former lawsuit," as it was filed years after Dr. Sasso's complaint in Indiana state court, the Federal Circuit's decision on appeal of that action did not bar its contrary ruling. ${ }^{433}$

The court also went out of its way to provide three reasons why it found the Federal Circuit's analysis of the Gunn factors unpersuasive. First, the court found the Federal Circuit's analysis to be "at best, cursory." distinguished the Federal Circuit's analysis for being based on Medtronic's declaratory judgment complaint, rather that Dr. Sasso's state court complaint. ${ }^{435}$ Third, the Federal Circuit affirmed the district court's decision not to exercise jurisdiction, albeit under the unrelated doctrine of abstention. ${ }^{436}$

Thus, since the defendants failed to show that the case met the four Gunn factors, Indiana's trial and appellate courts had subject matter jurisdiction over Dr. Sasso's contractual claims, and the court could hear the rest of the appeal. ${ }^{437}$

\section{Other Appealed Issues}

After analyzing the threshold issue of jurisdiction, the court went on to address the five remaining issues raised on appeal and ultimately affirmed on each. ${ }^{438}$

\section{BOARD DISCRETION IN INTER PARTES REVIEW: APPLE, INC. V. FINTIV, INC.}

In March 2020, the Board issued a precedential decision, providing guidance for how the Board will exercise its discretion under 35 U.S.C. § 314(a) in deciding whether to institute IPR. ${ }^{439}$ This decision is noteworthy, as it solidified the Board's controversial practice of considering the state of district court proceedings in deciding whether to institute IPR.

\section{A. Factual Background and Procedural History}

In October 2019, Apple, Inc., filed a petition for IPR of one of Fintiv's patents. ${ }^{440}$ In opposing Apple's petition, Fintiv urged the Board to exercise its discretion under 35 U.S.C. $\S 314(a)$ to deny institution of the requested proceeding "due to the advanced state of a parallel district court litigation in

432. Id. (emphasis in original).

433. Id.

434. Id. at 16 .

435. Id.

436. Id.

437. Id.

438. Id. at 25 .

439. Apple, Inc. v. Fintiv, Inc., No. IPR2020-00019, 2020 WL 2126495 (P.T.A.B. Mar. 20, 2020).

440. Id. at $* 1$. 
which the same issues have been presented and trial has been set for November 16, 2020. ${ }^{\prime 441}$ In support, Fintiv cited the Board's decision in NHK Spring Co. v. Intri-Plex Technologies, Inc., a relatively recent Board decision that had denied institution in light of a trial date which was set to occur earlier than the statutory deadline for the Board's final written decision. ${ }^{42}$ However, unlike in $N H K$ Spring, the Board's statutory deadline here for the final written decision preceded the date set for trial at the district court.

\section{B. Vice Chief Administrative Patent Judge Fink's Opinion}

Vice Chief Administrative Patent Judge Fink authored the Board's opinion, which extended the factors in NHK Spring to situations where the trial date is set after the IPR's projected statutory deadline. ${ }^{443}$ Each of the seven discussed factors collected authorities of other cases considering that factor.

1. Whether a Stay Exists or Is Likely to Be Granted if Proceeding Is Instituted.-If the district court has stayed their proceeding, or if the district court has denied the stay without prejudice with the option to obtain a stay upon renewed motion or subsequent $\mathrm{PTAB}$ filing, these facts disfavor the board exercising discretion to deny institution. ${ }^{444}$

But where the stay is denied, this favors institution. ${ }^{445}$ Even without a stay, the Board should also consider the second factor on the timing of the Board's decision, and the third factor on investment of resources in the district court. ${ }^{446}$

Where the district court has stayed pending the result of a parallel International Trade Commission (ITC) investigation, the board should consider exercising its discretion "to deny institution" where the ITC will reach its trial before the Board. ${ }^{447}$ This is so even though the district court and Board will not be bound by the ITC's decision, as it is practically difficult to maintain a district court litigation where the ITC has found the claims to be invalid. ${ }^{48}$

If there is a dispute before the ITC, the parties should indicate whether the district court has stayed proceedings pending the ITC's decision, and whether the ITC's decision will resolve all or substantially all of the patentability disputes between the parties, regardless of the district court's stay. ${ }^{449}$

441. Id.

442. Id.; NHK Spring Co. v. Intri-Plex Techs., Inc., No. IPR2018-00752, 2018 WL 4373643 (P.T.A.B. Sept. 12, 2018) (precedential, designated May 7, 2019).

443. Fintiv, 2020 WL 2126495, at*1 n.1; see 35 U.S.C. § 316(a)(11) (2018) (requiring that the Board issue its final written decision within one year of the institution decision, unless extended for up to six months for good cause).

444. Id. at *3.

445. Id.

446. Id.

447. Id. at $* 4$.

448. Id.

449. Id. at *3-4. 
2. Proximity of the Trial Court's Date to the Board's Projected Statutory Deadline.-Where the district court's trial date is before the projected statutory deadline, this favors exercising authority to deny institution. ${ }^{450}$ Where the trial date is around the same time as the projected statutory deadline, or even after the projected deadline, the Board should consider other factors, such as resources invested in the parallel proceeding. ${ }^{451}$

3. Investment in the Parallel Proceeding by the Court and Parties.-If the district court has issued substantive orders related to the patent or has issued claim construction orders before the institution decision, the Board should consider "denying institution" of the IPR because of the amount of resources invested in the district court proceeding. ${ }^{452}$ But where the district court has not issued orders related to the patent at issue in the petition, institution of the IPR is favored. ${ }^{453}$ This factor must be considered with the trial date factor and the stay factor, as the further a case is along, the more likely institution would lead to duplicative costs. ${ }^{454}$

The parties should explain the facts relevant to the timing of the filing of the petition. ${ }^{455}$ Even though the defendant-petitioner has one year to file a petition, waiting to petition may result in duplicative costs, which disfavors institution. ${ }^{456}$ Judge Fink suggests that petitioners explain when they knew which claims would be at issue in the district court, as this would make a delay in petitioning more permissible and less likely to lead to denial. ${ }^{457}$ But if the petitioner did not file expeditiously after learning the patent owner's intentions, then this factor favors exercising discretion to deny institution. ${ }^{458}$

4. Overlap Between Issues Raised in the Petition and in the Parallel Proceeding.- - If the petition is on grounds similar to those raised in the district court, this factor favors denial. ${ }^{459}$ But, if the petition includes materially different grounds, arguments, or evidence than those in the parallel proceeding, then this factor favors institution. ${ }^{460}$

This analysis will be highly fact dependent, especially where there is some overlap between the two proceedings. ${ }^{461}$ If the petition includes additional claims, the Board should investigate whether the district court's resolution of the smaller

450. Id. at *4; see Am. Axle \& Mfg., Inc. v. Neapco Holdings LLC, 966 F.3d 1347 (Fed. Cir. 2020).

451. Fintiv, 2020 WL 2126495 , at *4.

452. Id.

453. Id.

454. $I d$.

455. Id. at $* 5$.

456. Id.

457. Id.

458. Id.

459. Id.

460. Id.

461. Id. at $* 6$. 
set will resolve the key issues in the petition. ${ }^{462}$ The parties should indicate which challenged claims in the petition are also at issue in the district court. ${ }^{463}$

5. Whether the Petitioner and Defendant in the Parallel Proceeding Are the Same Party.-If the petitioner is unrelated to the defendant, then this factor favors institution. ${ }^{464}$ Conversely, if the petitioner is the defendant, then this factor disfavors institution. ${ }^{465}$ But even if the petitioner is unrelated to the defendant, institution may still be disfavored because the issues raised are the same as or substantially similar to those raised in another tribunal. ${ }^{466}$ The petitioner should address whether they are connected to a defendant, and whether the issues are similar to or different from the issues before the district court. ${ }^{467}$

6. The Merits of the Petition.-If the merits seem strong in the petition, this favors institution. ${ }^{468}$ This makes sure the overall system is efficient by allowing the Board to continue with the case, even if the parallel proceeding settles. ${ }^{469}$ But, if the merits are a close call, this favors denial of institution where other factors point towards denial. ${ }^{470}$ This factor does not require a full merits analysis, just that the Board consider the strengths or weaknesses of the petition. ${ }^{471}$

7. Other Considerations.-The filing of serial petitions, parallel petitions involving the same patent, and other considerations implicated by 35 U.S.C. $\S$ $325(\mathrm{~d})^{472}$ may also impact the board's decision to discretionarily deny institution. ${ }^{473}$ The parties should explain whether these other facts and circumstances exist in this case, and how institution would affect the "efficiency and integrity of the patent system." 474

\section{Aftermath}

Since this decision, parties and commentators have urged the Board to reconsider the practice, which they say encourages patent owners to forum shop cases to so-called rocket docket jurisdictions. ${ }^{475}$ One district court judge

\footnotetext{
462. Id.

463. Id.

464. Id.

465. Id.

466. Id.

467. Id.

468. Id.

469. Id.

470. $I d$.

471. Id.

472. Under 35 U.S.C. $§ 325(d)$, the Director may elect not to institute a proceeding if the challenge is based on the same or substantially similar arguments which were already before the

473. Fintiv, 2020 WL 2126495, at *7.

474. $I d$.

475. Others have commented on the Board's seemingly unfettered discretion in denying institution of IPR. See Joel D. Sayres \& Reid E. Dodge, Unfettered Discretion: A Closer Look at
} Board. 
seemingly encouraged the practice, commenting: "It's my job to give people the opportunity to have their cases tried in a federal court . . . and I probably can get a patent trial resolved more quickly than the PTAB can." ${ }^{476}$ In response to the decision, big tech companies Apple, Google, Cisco Systems, and Intel Corp. sued the Patent and Trademark Office, arguing that the Board's decision oversteps both patent law and the Administrative Procedure Act. ${ }^{477}$

the Board's Discretion to Deny Institution, 19 Chi.-Kent J. Intell. Prop. 536 (2020).

476. Britain Eakin, West Texas Judge Says He Can Move Faster than PTAB, Law360 (Nov. 27, 2019), https://www.law360.com/articles/1224105/west-texas-judge-says-he-can-move-fasterthan-ptab [https://perma.cc/4M5U-6C73].

477. See Apple Inc. v. Iancu, No. 5:20-cv-06128, 2021 WL 411157 (N.D. Cal. Feb. 5, 2021). 